STEVEN M. FAZZARI

Washington University

R. GLENN HUBBARD

Columbia University

BRUCE C. PETERSEN

Federal Reserve Bank of Chicago

\title{
Financing Constraints and Corporate Investment
}

EMPIRICAL models of business investment rely generally on the assumption of a "representative firm" that responds to prices set in centralized securities markets. Indeed, if all firms have equal access to capital markets, firms' responses to changes in the cost of capital or tax-based investment incentives differ only because of differences in investment demand. A firm's financial structure is irrelevant to investment because external funds provide a perfect substitute for internal capital. In general, with perfect capital markets, a firm's investment decisions are independent of its financial condition.

An alternative research agenda, however, has been based on the view that internal and external capital are not perfect substitutes. According to this view, investment may depend on financial factors, such as the availability of internal finance, access to new debt or equity finance, or the functioning of particular credit markets. For example, a firm's internal cash flow may affect investment spending because of a "financ-

We are grateful to members of the Brookings Panel for helpful comments and suggestions and to Charles Himmelberg and Jaewoon Koo for excellent research assistance. Financial support from the Federal Reserve Bank of Chicago is acknowledged. Hubbard acknowledges support from a John M. Olin Fellowship at the National Bureau of Economic Research. The views expressed here are not necessarily those of the Federal Reserve Bank of Chicago. 
ing hierarchy" in which internal funds have a cost advantage over new debt or equity finance. Under these circumstances, firms' investment and financing decisions are interdependent.

In this article, we link conventional models of investment to the recent literature on capital market imperfections and disparities in the access of individual firms to capital markets. Conventional representative firm models in which financial structure is irrelevant to the investment decision may well apply to mature companies with well-known prospects. For other firms, however, financial factors appear to matter in the sense that external capital is not a perfect substitute for internal funds, particularly in the short run. To provide a foundation for such an "imperfection," we appeal to problems in capital markets, especially asymmetric information, that make it very costly, even impossible, for providers of external finance to evaluate the quality of firms' investment opportunities. As a result, the cost of new debt and equity may differ substantially from the opportunity cost of internal finance generated through cash flow and retained earnings.

We begin by reviewing the role of financial factors in investment studies. We then document differences in financing patterns by size of firms and consider a variety of explanations why internal and external finance are not perfect substitutes. We use manufacturing firm data to analyze differences in investment in firms classified according to their earnings retention practices. If the cost disadvantage of external finance is small, retention practices should reveal little or nothing about investment: firms will simply use external funds to smooth investment when internal finance fluctuates, regardless of their dividend policy. If the cost disadvantage is significant, firms that retain and invest most of their income may have no low-cost source of investment finance, and their investment should be driven by fluctuations in cash flow.

We present tests of this hypothesis for the $q$, neoclassical, and accelerator models of investment. In each case, the investment of firms that exhaust all their internal finance is more sensitive to fluctuations in cash flow than that of mature, high-dividend firms. We also find a difference across firms in the sensitivity of investment to balance sheet variables that measure liquidity. Financial effects on investment are greatest at times when capital market information problems are likely to be most severe for high-retention firms, a finding that reinforces our thesis that financing constraints in capital markets affect investment. 
We test the robustness of these results to a wide variety of changes in estimation techniques and specifications.

We conclude by discussing the implications of our findings. For firms that face financing constraints, investment may be sensitive to the average tax burden as well as to marginal tax rates. Our results may also shed light on problems in industrial organization, such as financial motivations for conglomerate mergers. Finally, while capital market information problems arise at the level of the firm, financial constraints have a clear macroeconomic dimension because fluctuations in firms' cash flow and liquidity are correlated with movements of the aggregate economy over the business cycle. To the extent that a significant subset of firms faces financing constraints, their behavior may help explain aggregate movements of investment, and conclusions from models that maintain the representative firm assumption must be reexamined.

\section{Finance and the Study of Investment}

Early investment research, especially the work of John Meyer and Edwin Kuh, emphasized the importance of financial considerations in business investment. ${ }^{1}$ Indeed, financial effects on many aspects of real economic activity received broad attention during the early postwar period. ${ }^{2}$ Most research since the middle 1960s, however, has isolated real firm decisions from purely financial factors. Franco Modigliani and Merton Miller provided the theoretical basis for that approach by

1. John R. Meyer and Edwin Kuh, The Investment Decision: An Empirical Stady (Harvard University Press, 1957). Other contributions associated with the "Charles River School" of investment include James S. Duesenberry, Business Cycles and Economic Growth (McGraw-Hill, 1958); Kuh and Meyer, "Investment, Liquidity, and Monetary Policy," in Commission on Money and Credit, Impacts of Monetary Policy (Prentice Hall, 1963), pp. 339--474; and Meyer and Robert R. Glauber, Investment Decisions, Economic Forecasting, and Public Policy (Division of Research, Graduate School of Business Administration, Harvard University, 1964).

2. The influence of financial factors in real activity is provided by the "debt deflation" school associated with Irving Fisher, Hyman Minsky, and Charles Kindleberger. See Irving Fisher, "The Debt-Deflation Theory of Great Depressions," Econometrica, vol. 1 (October 1933), pp. 337-57; Hyman P. Minsky, John Maynard Keynes (Columbia University Press, 1975); Charles Kindleberger, Manias, Panics and Crashes (Basic Books, 1978). For the role of firm financial capacity in the credit intermediation process, see John G. Gurley and E. S. Shaw, "Financial Aspects of Economic Development," American Economic Review, vol. 45 (September 1955), pp. 515-38. 
demonstrating the irrelevance of financial structure and financial policy for real investment under certain conditions. ${ }^{3}$ Their key insight was that a firm's financial structure will not affect its market value in perfect capital markets. Thus, if the Modigliani-Miller assumptions are satisfied, real firm decisions, motivated by the maximization of shareholders' claims, are independent of financial factors such as internal liquidity, debt leverage, or dividend payments.

Applied to capital investment, this general finding provided a foundation for the neoclassical theory of investment developed by Dale Jorgenson and others, in which the firm's intertemporal optimization problem could be solved without reference to financial factors. ${ }^{4}$ Firms were assumed to face a cost of capital, set in centralized securities markets, that did not depend on the firm's particular financial structure. Since the development of the neoclassical theory, much empirical work, with both aggregate and firm-level data, has been devoted to tests of the relative success of various investment demand models, often without reference to the possible influence of financial factors.

Using data on 15 large manufacturing firms, Jorgenson and Calvin Siebert found the neoclassical model superior to internal funds theories of investment. Apart from their results, they preferred the neoclassical theory because it was consistent with the Modigliani-Miller finding that firm financial policy is irrelevant for investment. However, with a larger sample of 184 firms, J. W. Elliott reversed the Jorgenson-Siebert rankings, assigning the best ranking to the liquidity model. ${ }^{5}$

Subsequent comparative studies of investment demand models using aggregate time series data ranked alternative specifications based on statistical prediction error or goodness of fit. As an econometric issue, it is not obvious why these criteria are appropriate for comparative

3. Franco Modigliani and Merton H. Miller, "The Cost of Capital, Corporation Finance and the Theory of Investment," American Economic Review, vol. 48 (June 1958), pp. 26197; Merton H. Miller and Franco Modigliani, "Dividend Policy, Growth, and the Valuation of Shares," Journal of Business, vol. 34 (October 1961), pp. 411-33.

4. The neoclassical model is outlined in Robert E. Hall and Dale W. Jorgenson, "Tax Policy and Investment Behavior," American Economic Review, vol. 57 (June 1967), pp. 391-414.

5. Dale W. Jorgenson and Caivin D. Siebert, "A Comparison of Alternative Theories of Corporate Investment Behavior," American Economic Review, vol. 58 (September 1968), pp. 681-712; J. W. Elliott, "Theories of Corporate Investment Behavior Revisited," American Economic Review, vol. 63 (March 1973), pp. 195-207. 
analysis. Moreover, with formal nonnested specification tests of investment models estimated from quarterly time series data, and accounting for first-order serial correlation of the residuals, Ben Bernanke, Henning Bohn, and Peter Reiss find that all of the standard models are rejected by at least one other model. ${ }^{6}$

Apart from econometric issues, the assumption of representative firms is common to all this research-that is, the same empirical model applies to all firms regardless of the specification. Therefore, tests could not ascertain whether the observed empirical sensitivity of investment to financial variables differed in different kinds of firms. ${ }^{7}$ Thus, the representative firm paradigm limited the explanations that could be provided for financial effects.

The empirical work in this article relates the traditional study of financial effects on investment to recent literature on capital market imperfections by studying investment behavior in groups of firms with different financial characteristics. ${ }^{8}$ This change in empirical technique may help explain some aspects of the empirical paradoxes evident in past investment studies. If only certain classes of firms face capital market imperfections and corresponding financial constraints, the finding of Elliott, for example, that financial effects for a comparatively

6. For comparative studies, see Charles W. Bischoff, "Business Investment in the 1970s: A Comparison of Models," BPEA, 1:1971, pp. 13-58; Richard W. Kopcke, "The Behavior of Investment Spending during the Recession and Recovery, 1973-76," New England Economic Review (November-December 1977), pp. 5-41; Peter K. Clark, "Investment in the 1970s: Theory, Performance, and Prediction," BPEA, 1:1979, pp. 73113; Ben Bernanke, Henning Bohn, and Peter C. Reiss, "Alternative Non-Nested Specification Tests of Time-Series Investment Models," Journal of Econometrics, vol. 37 (March, 1988).

7. Robert Eisner's extensive study of firm-level data provides an exception to the typical assumption of representative firms. Eisner found that the timing of investment in small firms is more sensitive to profits than it is in large firms. Robert Eisner, Factors in Business Investment (Ballinger Press, 1978).

8. Much recent work has studied general financial effects on real economic activity. See Mark Gertler, "Financial Structure and Aggregate Economic Activity: An Overview," Journal of Money, Credit and Banking, forthcoming; Alan S. Blinder, "Credit Rationing and Effective Supply Failures,' Economic Journal, vol. 97 (June 1987), pp. 327-52; Charles W. Calomiris and R. Glenn Hubbard, "Price Flexibility, Credit Availability, and Economic Fluctuations: Evidence from the United States, 1879-1914" (Northwestern University, 1987); Ben S. Bernanke, "Nonmonetary Effects of the Financial Crisis in the Propagation of the Great Depression,"' American Economic Review, vol. 73 (June 1983), pp. 257-76; Charles W. Calomiris, R. Glenn Hubbard, and James H. Stock, "The Farm Debt Crisis and Public Policy," BPEA, 2:1986, pp. 441-79. 
broad sample of firms are significant need not conflict with the findings of Jorgenson and Siebert that a model emphasizing only real factors explains investment better for a group of well-known, mature firms. Both empirical approaches are appropriate in certain contexts. The problem, common to both, is the use of the representative firm assumption to explain investment for all firms. Therefore, the issue need not be posed as whether firm financial conditions "matter" for investment in some aggregate sense, or whether models of investment that emphasize financial variables fit the aggregate data better or forecast better than models that include only real variables.

\section{Sources and Cost of Finance}

As information on their sources and uses of funds shows, the financing practices of U.S. firms vary widely. ${ }^{9}$ Table 1 summarizes the financing practices of manufacturing firms during 1970-84, the same period covered by the sample of manufacturing firms analyzed later. We report the percentage of total finance coming from short-term bank debt, long-term bank debt, other long-term debt, and retained earnings for six firm size classifications. We also report the average retention ratio. The data exclude new equity issues, which are small in the aggregate. Financing obtained by small firms constitutes a nontrivial portion of the aggregrate. Firms with under $\$ 10$ million in assets accounted for 14 percent of the total finance raised over the period; firms with under $\$ 100$ million in assets, for 26 percent of the total.

Internal finance in the form of retained earnings generates the majority of net funds for firms in all size categories. ${ }^{10}$ The importance of internal

9. Early case studies suggested that small firms have more limited access to external finance than do large firms. See J. Keith Butters and John Lintner, Effect of Federal Taxes on Growing Enterprises (Division of Research, Graduate School of Business Administration, Harvard University, 1945); Meyer and Kuh, The Investment Decision; Gordon Donaldson, Corporate Debt Capacity: A Study of Corporate Debt Policy and the Determination of Corporate Debt Capacity (Division of Research, Graduate School of Business Administration, Harvard University, 1961).

10. This pattern has been true historically as well. U.S. manufacturing firms have relied heavily on internal finance for growth and development since at least the end of the nineteenth century. See, for example, the discussions by Lawrence H. Seltzer, A Financial History of the American Automobile Industry (Houghton Mifflin, 1928); and Meyer and Kuh, The Investment Decision. 
Table 1. Sources of Funds, by Asset Class, U.S. Manufacturing Firms, 1970-84

\begin{tabular}{|c|c|c|c|c|c|c|}
\hline \multirow[b]{2}{*}{ Firm size } & \multicolumn{4}{|c|}{ Source of funds (percent of total) ${ }^{\mathrm{a}}$} & \multirow{2}{*}{$\begin{array}{l}\text { Percen- } \\
\text { tage of } \\
\text { long-term } \\
\text { debt } \\
\text { from } \\
\text { banks }\end{array}$} & \multirow[b]{2}{*}{$\begin{array}{c}\text { Average } \\
\text { retention } \\
\text { ratio }\end{array}$} \\
\hline & $\begin{array}{c}\text { Short- } \\
\text { term } \\
\text { bank } \\
\text { debt }\end{array}$ & $\begin{array}{c}\text { Long- } \\
\text { term } \\
\text { bank } \\
\text { debt }\end{array}$ & $\begin{array}{l}\text { Other } \\
\text { long- } \\
\text { term } \\
\text { debt }\end{array}$ & $\begin{array}{l}\text { Retained } \\
\text { earnings }\end{array}$ & & \\
\hline All firms & 0.6 & 8.4 & 19.9 & 71.1 & 29.6 & 0.60 \\
\hline \multicolumn{7}{|l|}{ Asset class } \\
\hline Under $\$ 10$ million & 5.1 & 12.8 & 6.2 & 75.9 & 67.3 & 0.79 \\
\hline$\$ 10-50$ million & 5.9 & 17.4 & 6.9 & 69.8 & 71.6 & 0.76 \\
\hline$\$ 50-100$ million & 3.1 & 12.9 & 5.3 & 78.7 & 71.0 & 0.68 \\
\hline$\$ 100-250$ million & -0.2 & 13.3 & 12.0 & 74.9 & 52.4 & 0.63 \\
\hline$\$ 250$ million- $\$ 1$ billion & -2.3 & 10.6 & 15.4 & 76.3 & 40.8 & 0.56 \\
\hline Over $\$ 1$ billion & -0.6 & 4.8 & 27.9 & 67.9 & 14.7 & 0.52 \\
\hline
\end{tabular}

Source: Authors' calculations based on data taken from U.S. Department of Commerce, Bureau of the Census, Quarterly Financial Reports of Manufacturing, Mining, and Trade Corporations, various issues. The data underlying the calculations are expressed in 1982 dollars.

a. Funds raised from new equity issues are excluded from the calculations.

finance would be even greater if we were able to include information on depreciation allowances, a source of internal funds roughly equal to retained earnings. Furthermore, the proportion of earnings retained by firms differs substantially by size classes. The average retention ratio is almost 80 percent for the smallest firms in table 1 ; it drops monotonically as firm size increases, to a low of approximately 50 percent for firms with assets of more than $\$ 1$ billion. ${ }^{11}$

Differences in debt finance across size groupings are also important. Firms in the smallest classes accounted for the majority of net new shortterm bank debt. Firms with assets of less than $\$ 250$ million got most of their debt finance from banks-lending institutions specializing in monitoring borrowers through customer relationships-while firms with

11. It is not likely that differences in retention rates by size grouping are traceable solely to the relative tax price of dividends in determining payout for small corporations with concentrated ownership. For example, Dun and Bradstreet surveyed 365 ("small," "'medium-sized," and "large") manufacturing concerns in 1937 to determine the sources of increased net worth from 1920 to 1928 , a period in which the relative price of dividends and retentions (capital gains) to shareholders was virtually unity. Of small firms, 94 percent obtained more than 90 percent of their finance from retention, compared with 70 percent for large firms. Sixteen percent of large firms obtained at least haif of their finance from new share issues over the period, compared with only 1 percent of the small firms. The survey results are reviewed in detail in Willard L. Thorp and Edwin B. George, "An Appraisal of the Undistributed Profits Tax," Dun's Review (September 1937), pp. 5-36. 
assets of more than $\$ 1$ billion financed more than 85 percent of their new debt through nonbank sources.

Independent evidence by Philip Srini Vasan indicates that manufacturing corporations with assets of less than $\$ 100$ million raised only 2 percent of their total finance from net new share issues from 1960 to 1980. ${ }^{12}$ Srini Vasan also finds that internal finance is more volatile over the business cycle in small and medium-sized corporations than in large corporations. Moreover, during downturns, large firms have greater relative access to short-term and long-term debt markets. Hence, if internal and external sources of funds are not perfect substitutes, business recessions and changes in corporate tax policy that affect internal finance will likely have a greater effect on the growth rates and investment behavior of small, immature enterprises.

THE COST OF INTERNAL VERSUS EXTERNAL FINANCE

To provide a microfoundation for links between a firm's financial structure and its real investment spending, one must identify reasons why internal and external finance are not perfect substitutes in practice. In fact, explanations why internal finance may be less costly than new share issues and debt finance abound. Among the most prominent are transaction costs, tax advantages, agency problems, costs of financial distress, and asymmetric information. We emphasize asymmetric information between managers and potential new investors or creditors.

New Share Issues. New share issues of seasoned equity in the United States are typically carried out by underwriters who purchase a block of new shares and resell it. Relative to gross proceeds, the cost of a new share issue, including underwriting discounts, registration fees and taxes, and selling and administrative expenses, can vary substantially by size of offering. Costs for small offerings can be high. ${ }^{13}$ In addition, both direct and indirect costs of offerings are higher for initial public offerings than for seasoned offerings.

12. Philip Vijay Srini Vasan, "Credit Rationing and Corporate Investment" (Ph.D. dissertation, Harvard University, October 1986).

13. Transaction costs were recognized as a substantial impediment to the ability of small and medium-sized firms to raise equity capital in the 1930s. See U.S. Securities and Exchange Commission, "Cost of Flotation for Registered Securities, 1938-1939" (Washington, D.C.: Research and Statistics Section, Trading and Exchange Division, Securities and Exchange Commission, March 1941). 
The design of the corporate tax system in the United States and in other countries has historically imparted a cost advantage to internal equity finance over external equity finance. In the United States for many years, the effective tax rate on capital gains has been much lower than the tax rate on dividends. Recent studies show that this differential gives a cost advantage to internal finance; while no tax savings accrue from the issue of new shares, tax savings do arise when earnings are retained rather than paid out, because a dividend tax is replaced with a lower tax on capital gains.

Mervyn King and Alan Auerbach calculate shadow prices for the cost of internal finance $(r)$ and the cost of new share issues $(s) .{ }^{14}$ They establish that $r=\rho /(1-\tau)(1-c)$ and $s=\rho /(1-\tau)(1-\theta)$, where $\rho$ is the after-tax rate of return required by the capital market, $\tau$ is the corporate tax rate, and $c$ and $\theta$ are the tax rates on capital gains and dividends, respectively. The tax cost of new share issues can be expressed as $(s-r) / r=(\theta-c) /(1-\theta)$. Alternatively, within a $q$ framework, the threshold marginal $q$ value a project must attain to be undertaken depends on how it is financed. Shareholders benefit from externally financed projects only if their marginal $q$ exceeds unity. On the other hand, projects financed with retentions need only attain a $q$ of $(1-\theta) /(1-c)<1$.

Asymmetric information can generate potentially significant cost disadvantages of external finance for some kinds of firms. The theoretical arguments that support this view draw heavily on the "lemons" problem first considered by George Akerlof. ${ }^{15}$ The core of the argument is that

Clifford Smith finds that total costs as a percentage of proceeds in a sample of underwritten issues from 1971 to 1975 vary from 14 percent for issues under \$1 million to 4 percent for issues over $\$ 100$ million. Similar estimates of the cost differential by size of issue have been made in other studies. Clifford W. Smith, Jr., "Alternative Methods for Raising Capital: Rights versus Underwritten Offerings," Journal of Financial Economics, vol. 5 (December 1977), table 1, p. 277.

14. Mervyn A. King, Public Policy and the Corporation (London: Chapman and Hall, 1977); Alan J. Auerbach, "Wealth Maximization and the Cost of Capital," Quarterly Journal of Economics, vol. 93 (August 1979), pp. 433-46. See also David F. Bradford, "The Incidence and Allocation Effects of a Tax on Corporate Distributions," Journal of Public Economics, vol. 15 (February 1981), pp. 1-22; and the review of alternative approaches in James M. Poterba and Lawrence H. Summers, "The Economic Effects of Dividend Taxation," in Edward I. Altman and Marti G. Subrahmanyam, eds., Recent Advances in Corporate Finance (Homewood, Illinois: Richard D. Irwin, 1985), pp. 22784.

15. George A. Akerlof, "The Market for 'Lemons': Quality Uncertainty and the Market Mechanism," Quarterly Journal of Economics, vol. 84 (August 1970), pp. 488500 . 
some sellers with inside information about the quality of an asset or a security will be unwilling to accept the terms offered by a less-informed buyer. This may cause the market to break down, or at least force the sale of an asset at a price lower than it would command if all buyers and sellers had full information.

These ideas are applied to the problem of equity finance by Stewart Myers and Nicholas Majluf and by Bruce Greenwald, Joseph Stiglitz, and Andrew Weiss. In these "pecking order" or "financing hierarchy" theories, the firm's managers are assumed to have full information about the value of the firm's existing assets and the returns from new investment projects. ${ }^{16}$ Thus, to the extent that managers control sufficient internal funds to finance all profitable investment projects, investment demand models based on a representative firm in a perfect capital market apply. Suppose, however, that a firm exhausts all its internal funds and requires external finance to undertake a desirable project. In the Myers and Majluf model, external investors cannot distinguish the quality of firms; they value them all at the population average. Consequently, new shareholders implicitly demand a premium to purchase the shares of relatively good firms to offset the losses that will arise from funding lemons. The premium can raise the cost of new equity finance faced by managers of relatively high-quality firms above the opportunity cost of internal finance faced by existing shareholders.

The intuition behind the lemons premium can be described in terms of the $q$ model of investment. Following Myers and Majluf, we can say that an investment that requires new share issues will be undertaken only if it increases the wealth of existing shareholders. For good firms, the true gross returns from assets in place are denoted by $Y$ and the returns from a new project by $Y^{\prime}$. Myers and Majluf show that new shares will be issued only if

$$
Y^{\prime} / I \geq Y / V,
$$

16. Stewart C. Myers and Nicholas S. Majluf, "Corporate Financing and Investment Decisions When Firms Have Information That Investors Do Not Have," Journal of Financial Economics, vol. 13 (June 1984), pp. 187-221; Bruce Greenwald, Joseph E. Stiglitz, and Andrew Weiss, "Information Imperfections in the Capital Market and Macroeconomic Fluctuations," American Economic Review, vol. 74 (May 1984, Papers and Proceedings, 1983), pp. 194-99. The pecking-order view is described in Stewart C. Myers, "The Capital Structure Puzzle," Journal of Finance, vol. 39 (July 1984), pp. 57592. 
where $I$ is the cost of the new investment and $V$ is the market value assigned to both good firms and lemons. This condition is equivalent to requiring that the marginal $q$ on the new project at least equal the ratio of the firm's true average $q$-call it $q^{*}$-to the average $q$ assigned to all firms by the market $(\bar{q})$. With full information, $q^{*} / \bar{q}=1$, and the threshold $q$ value for issuing new shares would be unity, as in conventional models. When good firms initially cannot be distinguished from lemons, however, $q^{*} / \bar{q}$ will exceed unity for good firms. This ratio indicates how much dilution occurs when such firms issue new shares. The quantity $\left(q^{* /} \bar{q}\right)-1$ is the lemons premium that we denote by $\Omega$.

Debt Finance. Standard treatments of the effects of leverage on the firm's cost of funds posit an increasing marginal cost of new debt due to costs of financial distress and agency costs. Financial distress costs arise when a firm has difficulties meeting its principal and interest obligationsthe extreme case being bankruptcy. Agency costs arise from the limitedliability feature of debt contracts that creates incentives for firm managers to act counter to the interests of creditors under some circumstances.

Debt finance, particularly long-term debt, creates agency problems. The greater the debt-equity ratio, the more the incentives of managers who act in the interest of equity owners diverge from the interests of creditors. Managers may forgo some investment opportunities with positive net present values and accept others with negative present values. They also have incentives to issue new debt that raises the riskiness and lowers the value of existing debt. Because creditors understand the conflicts of interest that exist between themselves and equity holders, they demand covenants that restrict the behavior of managers, particularly with respect to new debt issues. ${ }^{17}$ As a result, covenants typically stipulate target debt-equity ratios. While they may provide a second-best solution to the contracting problem given the potential for opportunism, they are not costless, and their restrictions on financial flexibility limit management's choices of investment opportunities, as well as the ability to finance investment opportunities when internal funds are low. If covenants impose working capital requirements, for example, the supply of internal funds available to finance investment may be reduced. Hence, shocks to working capital, such as

17. See the description of covenants in Clifford W. Smith, Jr., and Jerold B. Warner, "On Financial Contracting: An Analysis of Bond Covenants," Journal of Financial Economics, vol. 7 (June 1979), pp. 117-61. 
a debt deflation or a decline in internal finance, will make debt finance more expensive at the margin, probably at a time when the need for new debt is most acute.

Asymmetric information in markets for debt can cause distortions similar to those discussed previously for new share issues. Asymmetric information may increase the cost of new debt, or even result in credit rationing. Dwight Jaffee and Thomas Russell show that the market interest rate must rise, and loan size may be limited, when lenders cannot distinguish borrower quality. ${ }^{18}$ Stiglitz and Weiss demonstrate that "equilibrium credit rationing" can arise from adverse selection. Again, the lemons argument is critical. Lenders cannot price discriminate between good borrowers and bad in loan contracts because of asymmetric information. Thus, when interest rates rise, relatively good borrowers drop out of the market, increasing the probability of default and possibly reducing the lenders' expected profit. In equilibrium, lenders may set an interest rate that leaves an excess demand for loans in the market. Some borrowers receive loans while other observationally equivalent borrowers are rationed. ${ }^{19}$

Calomiris and Hubbard add heterogeneous debt markets and agents that are restricted from borrowing in some markets to the Stiglitz-Weiss structure. ${ }^{20}$ Two credit markets, a "full-information" market (bond or commercial paper, for example) and a bank loan market, coexist. The banks specialize in financing projects of borrowers for which information problems are more severe, in the sense that costs of obtaining borrower information are high and lenders can reduce average information costs by maintaining long-term relationships. The central proposition in this work is that, depending on per capita levels of internal net worth, the

18. Dwight M. Jaffee and Thomas Russell, "Imperfect Information, Uncertainty and Credit Rationing," Quarterly Journal of Economics, vol. 90 (November 1976), pp. 651-66.

19. Joseph E. Stiglitz and Andrew Weiss, "Credit Rationing in Markets with Imperfect Information," American Economic Review, vol. 71 (June 1981), pp. 393-410.

20. Charles W. Calomiris and R. Glenn Hubbard, "Firm Heterogeneity, Internal Finance, and Credit Rationing," Working Paper 2497 (National Bureau of Economic Research, January 1988). In addition, the importance of borrower net worth for obtaining external finance is stressed by Hayne E. Leland and David H. Pyle, "Informational Asymmetries, Financial Structure, and Financial Intermediation," Journal of Finance, vol. 32 (May 1977), pp. 371-87; Myers and Majluf, "Corporate Financing Decisions"'; Ben S. Bernanke and Mark Gertler, "Financial Fragility and Economic Performance," Working Paper 2318 (NBER, July 1987). 
allocation of new funds to classes of borrowers could either follow the full-information credit allocation or ration funds away from some classes of borrowers who would receive credit in the absence of asymmetric information. A "financial collapse" may occur, in which some or all classes of asymmetric-information borrowers are denied loans.

Finally, while it is generally true that higher leverage entails a higher shadow price of funds, only the largest and most mature firms are likely to face a smoothly increasing loan interest rate. Several features of heterogeneity are important here. Small and medium-sized firms are less likely to have access to impersonal centralized debt markets. Indeed, outside the Fortune 500 companies, the overwhelming majority of bond finance has been obtained historically through private placements, usually with life insurance companies or pension funds. Two features of private placements are significant. First, they are more restrictive than typical bond arrangements, requiring minimum levels of working capital and stockholders' equity and often limiting dividend payments and capital spending. Second, during periods of tight credit, small and medium-sized borrowers are often denied loans in favor of better-quality borrowers, who could also obtain funds from centralized securities markets. Similarly, bank loans and lines of credit, the typical source of finance for smaller industrial firms, restrict operating flexibility and require particular levels for certain financial operating ratios. ${ }^{21}$ With constant investment opportunities, it is precisely in times of a decline in

21. With respect to private placements, see the extensive discussion in Eli Shapiro and Charles Wolf, who note that from 1953 to 1970, Fortune 500 companies obtained an average of 37 percent of their bond finance through private placements, compared with an average of 75 percent for other manufacturing firms. Eli Shapiro and Charles R. Wolf, The Role of Private Placements in Corporate Finance (Division of Research, Graduate School of Business Administration, Harvard University, 1972), p. 150.

With respect to bank finance, see the analysis of data for manufacturing firms from the Quarterly Financial Reports of the U.S. Bureau of the Census in Srini Vasan, "Credit Rationing," chap. 3. Although small businesses can borrow from commercial banks, the banks cannot (absent secured mortgages) furnish long-term funds as a substitute for equity or bonds; maturities of from three to five years are typically the longest available. The Small Business Administration, which can guarantee loans of longer maturities, is not active in industrial finance; see Barry P. Bosworth, Andrew S. Carron, and Elizabeth H. Rhyne, The Economics of Federal Credit Programs (Brookings, 1987).

For the use of financial ratios as a predictor of bankruptcy, see Edward I. Altman, "Financial Ratios, Discriminant Analysis and the Prediction of Corporate Bankruptcy," Journal of Finance, vol. 23 (September 1968), pp. 589-609. 
internal finance that such firms cannot obtain debt finance on the margin for capital spending projects.

As we noted before, covenants in debt contracts protect the interests of bondholders from opportunistic behavior on the part of shareholders. To the extent that difficulties in contracting in debt markets are related only to agency problems and not to asymmetric information, equity markets could provide the marginal source of external finance for firms. However, firms facing asymmetric information problems in credit markets will also probably need to pay a premium to obtain new equity. Therefore, equity finance will not, in general, solve asymmetric information problems associated with debt.

\section{“Financing Hierarchies" and Investment}

The preceding discussion of the cost premium that some firms must pay for external finance can be integrated into a model of firm financial and investment decisions developed in the public finance literature (see Appendix A and the references therein). In the standard model, the value of a firm, $V$, is the present value of the posttax dividend stream adjusted for the amount of new share issues, $V^{N}$, that current equity holders would have to purchase to maintain their proportional claim on the firm. Formally, the value of the firm is

$$
V_{t}=\sum_{i=0}^{\infty}\left(1+\frac{\rho}{1-c}\right)^{-(i-1)}\left[\left(\frac{1-\theta}{1-c}\right) D_{t+i}-V_{t+i}^{N}\right],
$$

where $\rho$ is the required return on equity, $D_{t}$ represents the dividend payment in period $t, \theta$ is the tax rate on dividends, and $c$ is the tax rate on capital gains. Managers maximize the value of existing shareholders' stock subject to a set of constraints on the distribution of earnings (see Appendix A). The solution for the case of $\theta>c$ is well known; it is never optimal to issue new shares and pay dividends at the same time. Here, whenever internal finance exceeds desired investment, $q$ is $(1-\theta) /(1-c)<1$ in equilibrium, as discussed previously. A valuemaximizing firm will issue new shares only after it exhausts internal finance and $q>1$. Thus, the breakeven $q$ a project must attain depends on how it will be financed.

The same kind of logic applies to firms facing asymmetric information, but the cost differential between internal and external finance may be 
much larger. The above expression for $V_{t}$ can be modified to include a lemons premium demanded by potential new equity investors when asymmetric information problems exist. We reduce $V_{t}$ in equation 1 by an amount $\Omega_{t}$ per dollar of new equity issued, or

$$
V_{t}=\sum_{i=0}^{\infty}\left(1+\frac{\rho}{1-c}\right)^{-(i-1)}\left[\left(\frac{1-\theta}{1-c}\right) D_{t+i}-\left(1+\Omega_{t+i}\right) V_{t+i}^{N}\right]
$$

where $\Omega$ reflects the additional value that new investors demand from good firms to compensate them for the losses they incur from inadvertently funding lemons. With this modification to the model, the breakeven $q$ value for investment projects financed by new share issues becomes $1+\Omega$.

This financing hierarchy is depicted in figure 1 . The solid lines in the figure represent a simple case of a discontinuous differential in the costs of internal and external equity finance. ${ }^{22}$ When investment demand is low, as with the $D_{1}$ schedule, capital spending can be financed from internally generated funds, at the expense of extra dividends. At very high levels of investment demand, as with the $D_{3}$ schedule, firms will issue new shares. The higher the value of $\Omega$, the greater the likelihood that internal finance will constrain a firm's investment, as illustrated by the $D_{2}$ schedule. Of course, the lemons premium can vary both across firms and over time for the same firm. If information problems become less severe, the top horizontal schedule in figure 1 will shift downward toward unity.

Debt finance can also be incorporated. To the extent that debt can be secured, or obtained from lenders, such as commercial banks, that specialize in monitoring the borrower, information problems in debt markets will be less severe than those in external equity markets, but the marginal cost of debt will increase with leverage, as discussed

22. Some recent studies have tested for implied cost differences between internal and external equity finance. See Robert L. McDonald and Naomi Soderstrom, "Dividend and Share Changes: Is There a Financing Hierarchy?'” Working Paper 2029 (NBER, September 1986); Avner Kalay and A. Shimrat, "On the Payment of Equity-Financed Dividends" (New York University, December 1985); Kalay and Shimrat, "Firm Value and Seasoned Equity Issues: Price Pressure, Wealth Distribution, or Negative Information,"' Working Paper 894/86 (New York University, March 1986). Also see Paul Asquith and David W. Mullins, Jr., "Equity Issues and Offering Dilution," Journal of Financial Economics, vol. 15 (January-February 1986), pp. 61-89; and Ronald Masulis and A. N. Korwar, "Seasoned Equity Offerings: An Empirical Investigation," Journal of Financial Economics, vol. 15 (January-February 1986), pp. 91-118. 
Figure 1. Investment and Financing Decisions

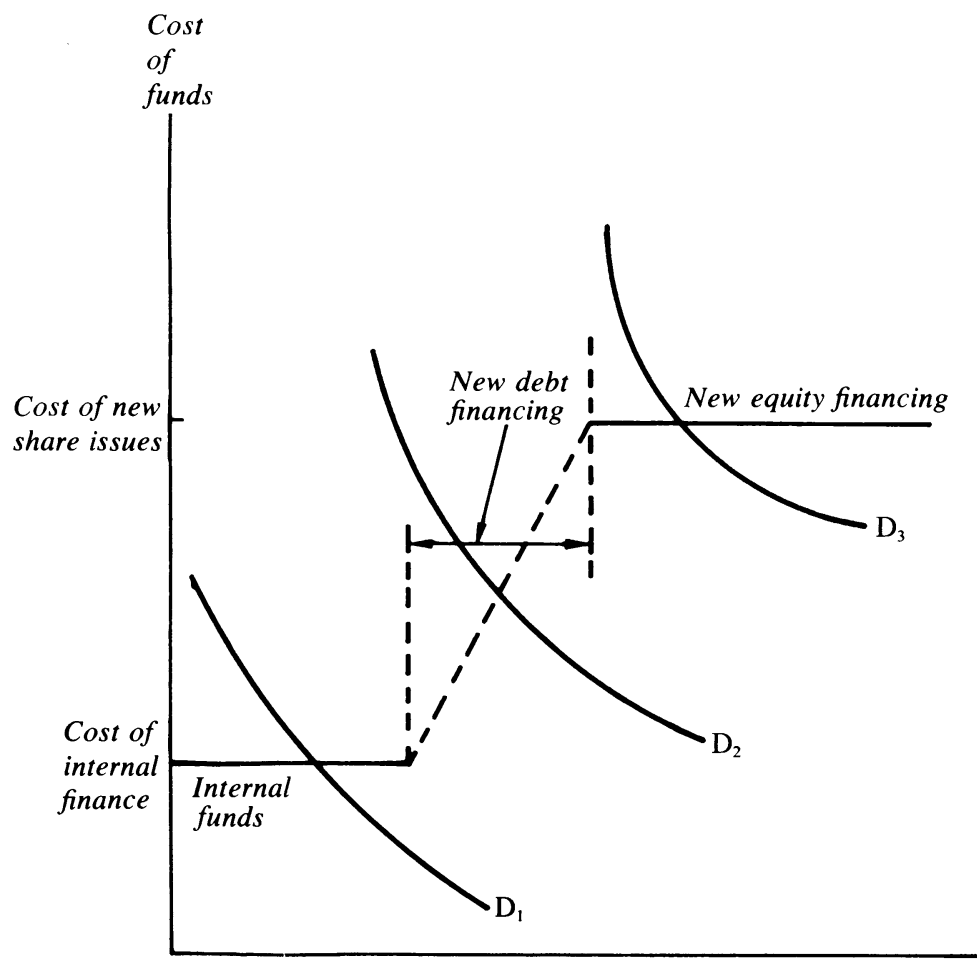

Total investment financing

previously. This modified hierarchy is illustrated by the dotted line in figure 1 that connects the two horizontal segments in the middle range of the figure. Hence, intermediate levels of investment demand, as illustrated by the $D_{2}$ schedule, will be financed by a mix of internal funds and debt.

This financing hierarchy has a number of implications for $q$ values and investment behavior. First, all other things equal, observed $q$ values will differ in firms with different information characteristics. For firms facing asymmetric information, the observed $q$ value will be the value assigned by the imperfectly informed market. The model also predicts that $q$ must be substantially higher to induce a new share issue for limited-information (high $\Omega$ ) firms than for full-information (low $\Omega$ ) firms.

The true marginal $q$ is unobservable; we can, however, observe the 
average $q$ assigned by the market and its relationship to new share issues. Observed $q$ can move independently from the true valuation for limitedinformation firms. For example, the market may reappraise the underlying probability that a firm is a lemon. If the asymmetric information problem is important empirically, observed $q$ values should be high relative to historical values before new share issues for limited-information firms.

Finally, internal finance constrains spending for firms that do not pay dividends and face an investment demand schedule like $D_{2}$ in figure 1 . When $q$ is sufficiently high, new shares are issued, and movements in $q$ lead to movements in investment. Otherwise, investment will be driven by changes in internal finance. In the limiting case, with a vertical debt supply schedule, variations in the length of the retention segment in figure 1 should cause corresponding variations in investment for firms that pay no dividends. More generally, the slope of the debt supply schedule will determine the extent to which firms can offset reductions in internal finance with greater leverage. Therefore, the larger the lemons premium, $\Omega$, the greater the chances that a firm will have an investment demand curve like $D_{2}$, where investment opportunities, as measured by a project's marginal $q$, can vary, while investment responses are affected by the availability of internal finance. Such a pattern resembles the predictions of sales-accelerator models of investment; we discuss this point in more detail later.

In summary, if the cost of capital differs by source of funds, the availability of finance will likely have an effect on the investment practices of some firms. In financing hierarchy models like the one summarized in figure 1, the availability of internal funds allows firms to undertake desirable investment projects without resorting to high-cost external finance. In addition, to the extent that a firm seeks debt finance at the margin, greater internal cash flow enhances its balance sheet and net worth positions, lowering the cost of new debt.

\section{Differences in Firm Financing Practices}

To examine the empirical importance of these ideas for explaining investment, we use a large panel of Value Line data for manufacturing firms. The details of the sample structure and definitions of the empirical variables are discussed in Appendix B. The firms in this data base are 
typically large, and their stock is publicly traded. Evidence that some of these firms face financing constraints should indicate that the phenomenon is widespread.

Our approach is to study differences in financing and investment in groups of firms with different characteristics. Observed retention practices provide a useful a priori criterion for identifying firms that are likely to face relatively high costs of external finance. If the cost disadvantage of external finance is large, it should have the greatest effect on firms that retain most of their income. If the cost disadvantage is slight, then retention practices should reveal little about financing practices, $q$ values, or investment behavior. ${ }^{23}$

Our classification scheme divides firms into three groups. Class 1 firms have a ratio of dividends to income less than 0.1 for at least 10 years. Class 2 firms have a dividend-income ratio less than 0.2 , but more than 0.1 , for at least 10 years. Class 3 includes all other firms.

We considered further divisions of the high-paycut firms in class 3 , but we did not find substantial differences between firms that paid out 20-40 percent of their income on average as dividends and firms that paid out more than 40 percent. Because of possible outliers of the dividend-income ratio, due to abnormally low income in a particular year, this approach is more robust than classifying firms according to their average retention ratio.

One reason why firms might pay low dividends is that they require investment finance that exceeds their internal cash flow and retain all of the low-cost internal funds they can generate. A second is that they have little or no income to distribute. We are interested in the first group and, for this reason, have included only those firms in the sample that had positive real sales growth from 1969 through 1984. To avoid any biases across retention classes, this restriction was applied to all firms in the sample, not just the low-dividend class. The results that follow were not changed substantially by including firms with negative sales growth in the sample.

23. Our scheme for grouping firms according to differences in dividend behavior is similar to tests for the presence of liquidity constraints on consumption, in which households are grouped into high-wealth and low-wealth categories. See for example Fumio Hayashi, "The Effect of Liquidity Constraints on Consumption: A Cross-Sectional Analysis," Quarterly Journal of Economics, vol. 100 (February 1985), pp. 183-206; and Stephen P. Zeldes, "Consumption and Liquidity Constraints: An Empirical Investigation," Working Paper 24-85 (Rodney L. White Center for Research, Wharton School, University of Pennsylvania, November 1985). 
Table 2. Summary Statistics: Sample of Manufacturing Firms, 1970-84

\begin{tabular}{|c|c|c|c|}
\hline \multirow[b]{2}{*}{ Statistic } & \multicolumn{3}{|c|}{ Category of firm } \\
\hline & Class $1^{\mathrm{a}}$ & Class $2^{\mathrm{b}}$ & Class $3^{\mathrm{c}}$ \\
\hline Number of firms & 49 & 39 & 334 \\
\hline Average retention ratio & 0.94 & 0.83 & 0.58 \\
\hline Percent of years with & & & \\
\hline positive dividends & 33 & 83 & 98 \\
\hline $\begin{array}{l}\text { Average real sales growth } \\
\text { (percent per year) }\end{array}$ & 13.7 & 8.7 & 4.6 \\
\hline $\begin{array}{l}\text { Average investment- } \\
\text { capital ratio }\end{array}$ & 0.26 & 0.18 & 0.12 \\
\hline $\begin{array}{l}\text { Average cash flow- } \\
\text { capital ratio }\end{array}$ & 0.30 & 0.26 & 0.21 \\
\hline $\begin{array}{l}\text { Average correlations of } \\
\text { cash flow with investment } \\
\text { (deviations from trend) }^{d}\end{array}$ & 0.92 & 0.82 & 0.20 \\
\hline $\begin{array}{l}\text { Average of firm standard } \\
\text { deviations of investment- } \\
\text { capital ratios }\end{array}$ & 0.17 & 0.09 & 0.06 \\
\hline $\begin{array}{l}\text { Average of firm standard } \\
\text { deviations of cash flow- } \\
\text { capital ratios }\end{array}$ & 0.20 & 0.09 & 0.06 \\
\hline Capital stock (millions of 1982 & & & \\
\hline Average capital stock, 1970 & 100.6 & 289.7 & $1,270.0$ \\
\hline Median capital stock, 1970 & 27.1 & 54.2 & 401.6 \\
\hline Average capital stock, 1984 & 320.0 & 653.4 & $2,190.6$ \\
\hline Median capital stock, 1984 & 94.9 & 192.5 & 480.8 \\
\hline
\end{tabular}

Several summary statistics for the firms in each class are presented in table 2. Our class 1 firms, those that we hypothesize will more likely face binding financial constraints, retained an average of 94 percent of their income and paid a dividend in only 33 percent of the years. Many of these firms paid no dividends for the first 7 to 10 years and a small dividend in the remaining years. In fact, 20 firms never paid a dividend.

Class 1 firms experienced much more rapid growth in the fixed capital stock than the mature firms in class 3. Mean values of the capital stock are, of course, influenced by extreme values. The growth pattern for median values is similarly striking. While class 1 firms are smaller than firms in class 3 , they are still large relative to U.S. manufacturing corporations in general; 85 percent of manufacturing corporations had 
smaller capital stocks in 1970 than the average class 1 firm. ${ }^{24}$ Firms in class 1 have a high mean investment-to-capital ratio, and they exhaust nearly all of their cash flow on investment spending. Firms in class 3 spend a much lower proportion of their cash flow on investment. Both cash flow and investment are more volatile in class 1 , as the standard deviation statistics in table 2 indicate. Table 2 also shows a striking difference in the correlation of deviations from exponential trends of cash flow and investment between classes 1 and 2 and class 3 . These statistics are estimated from time series constructed by aggregating the sample data within each class. The correlations suggest the greater sensitivity of investment to cash flow in classes 1 and 2 that we find in the regression equations that follow.

The data in table 3 present information on new share issues, debt finance, and $q$ values for firms in the various classes. ${ }^{25}$ Other things being equal, one would expect firms in class 1 to rely more heavily on new share issues than firms in the remaining classes. The typical firm in class 1 has an investment demand schedule like $D_{2}$ or $D_{3}$ in figure 1. The typical firm in class 3 has a demand schedule like $D_{1}$ and should not simultaneously pay dividends and issue new shares, given the historical differences in dividend and capital gains tax rates. Consistent with their rapid growth, firms in class 1 issue new shares more frequentlyapproximately one year in every four-than the firms in the other classes. Firms in the first class also raise a greater proportion of total finance from new shares. Even for class 1 firms, however, new share issues provide a much smaller proportion of total funds than internal cash flows.

24. We estimated a probit model for the probability that a firm is included in class 1as a function of size (capital stock in 1977), average real sales growth over the sample period, the average value of $q$, the average value of the ratio of outstanding debt to the market value of debt and equity, and the standard deviation of earnings (measured relative to the capital stock). The results are consistent with what one would expect based on the summary statistics reported in table 2 . While firms in class 1 are smaller on average than firms in class 3 , size as such does not appear to be the dominant factor explaining why firms fall into the high-retention class 1 . The size variable in the probit equation has a negative estimated coefficient, but it is not as statistically or economically significant as the estimated coefficients for most of the other variables.

25. Some firms reported infrequent, but very small new share issues that were probably associated with executive stock option plans. In the calculations presented in table 3, we excluded such small issues by requiring that funds raised from new common stock exceed 10 percent of the firm's cash flow in the same year; stock splits are also excluded. 
Table 3. New Share Issues, Tobin's $q$, and Debt Statistics

for Manufacturing Firms, 1970-84

\begin{tabular}{|c|c|c|c|}
\hline Item & Class 1 & Class 2 & Class 3 \\
\hline $\begin{array}{l}\text { Average percentage of years } \\
\text { with new share issues }\end{array}$ & 28 & 19 & 10 \\
\hline $\begin{array}{l}\text { Average value of share issues as } \\
\text { a percentage of cash flow }\end{array}$ & 23 & 13 & 8 \\
\hline Average annual $q$ values $^{\mathrm{a}}$ & $\begin{array}{c}3.8 \\
(0.4)\end{array}$ & $\begin{array}{c}2.4 \\
(0.2)\end{array}$ & $\begin{array}{c}1.6 \\
(0.1)\end{array}$ \\
\hline Median $q$ values & 1.6 & 1.4 & 1.0 \\
\hline $\begin{array}{l}\text { Average difference in } q \text { values } \\
\text { between periods of new share } \\
\text { issues and periods of no new } \\
\text { share issues }^{\mathrm{a}}\end{array}$ & $\begin{array}{c}1.6 \\
(0.8)\end{array}$ & $\begin{array}{c}0.9 \\
(0.4)\end{array}$ & $\begin{array}{c}0.2 \\
(0.1)\end{array}$ \\
\hline $\begin{array}{l}\text { Average ratio of debt to } \\
\text { capital stock }\end{array}$ & 0.57 & 0.52 & 0.33 \\
\hline $\begin{array}{l}\text { Average ratio of interest } \\
\text { payments to sum of interest } \\
\text { payments plus cash flows }\end{array}$ & 0.27 & 0.21 & 0.17 \\
\hline $\begin{array}{l}\text { Correlation of the earnings-to- } \\
\text { capital ratio and the change in } \\
\text { total debt-to-capital ratio } \\
\text { (averaged over firms) }\end{array}$ & 0.23 & 0.15 & 0.09 \\
\hline
\end{tabular}

Source: Same as table 2.

a. The standard error of the mean appears in parentheses.

The last three lines of table 3 provide information on debt use. Although one would expect the firms in class 3 to have higher debt capacities, the debt-to-capital and interest expense ratios are higher for classes 1 and 2 . These results are consistent with a financing hierarchy and support the idea that constrained firms borrow up to their debt capacity. ${ }^{26}$ Nor is there any indication in the data that debt issues smooth fluctuations in cash flow. For 43 of the 49 class 1 firms, the correlation of the earnings-to-capital ratio with the change in the total debt-to-capital ratio is positive. As shown in table 3 , the average correlation of earnings

26. The pattern of debt leverage across classes also holds for debt-equity ratios measured as the book value of debt divided by the book value of common equity. For the empirical effect of debt service on investment, see Allen Sinai and Otto Eckstein, "Tax Policy and Business Fixed Investment Revisited," Journal of Economic Behavior and Organization, vol. 4 (June-September 1983), pp. 131-62; Steven M. Fazzari and Michael J. Athey, "Asymmetric Information, Financing Constraints, and Investment," Review of Economics and Statistics, vol. 69 (August 1987), pp. 481-87. 
with the change in debt is positive for all classes, but it is largest for class 1. This result also holds up in regressions that control for investment opportunities through $q$. The change in either long-term or total debt is positively related to cash flow when it is regressed on $q$ and cash flow (all variables were deflated by the capital stock). Therefore, changes in debt appear to reinforce rather than offset fluctuations in cash flow, especially for class 1 firms, for which the positive estimated sensitivity of changes in debt to cash flow fluctuations was the largest. ${ }^{27}$

Table 3 also reports Tobin's $q$ measures for all three classes of firms. ${ }^{28}$ The average $q$ value for the first two classes is significantly greater than the averages for the third. The asymptotic $t$-statistic for the null hypothesis that the first class mean equals the third class mean is 5.8. This result also holds for every year in the sample individually. Similar patterns hold for median $q$ values.

One might interpret the high $q$ values observed in class 1 as the result of high expected growth rates. As table 1 shows, firms in this class did indeed grow quickly over our sample period. Their high $q$ values, however, beg the question of why they did not invest even more. As an alternative to financing constraints, high adjustment costs could slow convergence of $q$ to a full-information equilibrium. Then, one would expect no systematic relation between $q$ and new share issues. Firms would invest at an optimal pace to push $q$ uniformly toward equilibrium, and new shares would be issued as necessary to finance capital spending.

The statistics in table 3, however, strongly contradict this view. We calculate the differences in $q$ values in years with and without new share

27. A more detailed examination shows that for 21 of the class 1 firms, cash flow declined 25 percent or more on one or two occasions. In almost all cases, cash flow growth returned to normal in the next period, and the cash flow shock appeared to be temporary. In 26 cases, the debt-to-capital ratio either fell or remained unchanged in the next period; the ratio increased in only 5 instances. The evidence also indicates that debt is not on average an important source of bridge finance between new equity issues for these firms. If new debt were issued in the interim between new stock offerings, and the proceeds from the new equity were used to pay off debt, one would expect a negative correlation between new share issues and the change in debt. For the firms in our sample, however, the correlations between new equity finance and the changes in both total and long-term debt were essentially zero in all classes.

28. For measures of tax-adjusted $Q$ (see the definition in Appendix B), the patterns were even more pronounced. The unadjusted $q$ values reported were calculated with the book value of debt. The results were almost identical with various estimates of the market value of debt (see Appendix B). 
issues on a firm-by-firm basis and then average these differences. ${ }^{29}$ As noted in the table, for the three classes of firms, this procedure yields differences of, respectively, 1.6, 0.9, and 0.2. As discussed earlier, these results are consistent with a financing hierarchy.

\section{Financial Constraints in Empirical Models of Investment}

The theories discussed here imply that the supply of investment finance is not perfectly elastic for firms that face asymmetric information problems in capital markets. This result is independent of how one models the demand side of the investment decision. Indeed, the investment demand curve presented in figure 1 could be based on a $q$ model of investment or a neoclassical model. Regardless of the true economic process at the foundation of investment demand, the supply of low-cost finance, and therefore the level of internal cash flow, enters the reducedform investment equation of firms for which internal and external finance are not perfect substitutes.

In view of the longstanding debates in the literature over the appropriate specification of the model's demand side, we examine three broad empirical specifications that encompass the most common approaches: models based on $q$ that emphasize market valuations of the firm's assets as the determinant of investment, sales accelerator models in which fluctuations in sales or output motivate changes in capital spending, and neoclassical models that combine measures of output and the cost of capital to explain investment demand. The most extensive tests of alternative specifications and estimation techniques are presented for the $q$ model. These tests lead to similar conclusions for the other models.

29. The average differences reported in table 3 are computed as follows. We first compute the average difference on a firm-by-firm basis for all firms that issued shares, as defined above, in at least one of our sample years. These statistics are then averaged across firms in each class to obtain the results in table 2. Thus, differences in average $q$ levels between firms that issue shares and firms that do not would not affect the reported statistics. Similar results can be obtained by regressing $q$ on year dummies and a dummy variable for the new share issues.

An alternative explanation of the high $q$ values in the firms in class 1 is the relative importance of "intangibles" for such firms. It is difficult, however, to link that explanation to the large differences in $q$ values between periods in which new shares are issued and periods in which they are not. 
The general form of the reduced-form investment equations that we examine is

$$
(I / K)_{i t}=f(X / K)_{i t}+g(C F / K)_{i t}+u_{i t},
$$

where $I_{i t}$ represents investment in plant and equipment for firm $i$ during period $t ; X$ represents a vector of variables, possibly including lagged values, that have been emphasized as determinants of investment from a variety of theoretical perspectives; and $u$ is an error term. The function $g$ depends on the firm's internal cash flow $(C F)$; it represents the potential sensitivity of investment to fluctuations in available internal financeafter investment opportunities are controlled for through the variables in $X .{ }^{30} \mathrm{We}$ analyze other measures of internal liquidity later. All variables are divided by the beginning-of-period capital stock $K$.

As we stressed in our review of the implications of information problems in capital markets, empirical analysis must allow for systematic differences in the effect of potential finance constraints across firms. Our classification scheme based on retention practices identifies firms that are most likely to face capital market imperfections and the corresponding finance constraints. The evidence on firm financial behavior and $q$ values across our retention classes, presented in the previous section, supports this view. If information problems in capital markets lead to financing constraints on investment, they should be most evident for the classes of firms that retain most of their income. If internal and external finance are nearly perfect substitutes, however, then retention practices should reveal little about investment by the firm. Firms would simply use external finance to smooth investment when internal finance fluctuates.

This test does not simply restate the accounting identity that sources equal uses of funds. Investment spending must be financed somehow, and cash flow provides a source of finance. Under an assumption of perfect capital markets, however, there is no reason to expect internal finance fluctuations to have different effects in firms with different

30. Other empirical studies that consider the effect of internal funds on investment include Kuh and Meyer, "Investment, Liquidity, and Monetary Policy"; Robert M. Coen, "The Effect of Cash Flow on the Speed of Adjustment," in Gary Fromm, ed., Tax Incentives and Capital Spending (Brookings, 1971), pp. 131-94; Eisner, Factors in Business Investm $\rightarrow$ Steven M. Fazzari and Tracy L. Mott, "The Investment Theories of Kalecki and Keynes: An Empirical Study of Firm Data, 1970-1982,"' Journal of Post Keynesian Economics, vol. 9(Winter 1986-87), pp. 171-87. 
retention behavior. Internal funds constitute only one possible source of investment finance, and their availability should not constrain investment unless the firm must pay a premium for new debt or equity finance.

\section{INTERNAL FUNDS IN A $Q$ MODEL OF INVESTMENT}

We begin our empirical investigation of financing constraints and investment within the $q$-theory framework. ${ }^{31}$ The intuition of the model is that, absent considerations of taxes or capital market imperfections, a value-maximizing firm will invest as long as the shadow value of an additional unit of capital, marginal $q$, exceeds unity. In equilibrium, the value of an extra unit of capital is just its replacement cost, so that marginal $q$ is unity. The conceptual advantage of this framework in modeling the effects of internal finance on investment is that $q$ controls for the market's evaluation of the firm's investment opportunities. ${ }^{32}$

We employ an empirical specification derived from an adjustment cost technology, and follow Lawrence Summers in specifying a cost of adjustment per unit of investment relative to capital. In the absence of financing constraints, Fumio Hayashi and Summers have linked the shadow price to the market value of existing capital (that is, average $q$ ). In that approach, under quadratic adjustment costs, investment is determined according to

$$
(I / K)_{i t}=\mu_{i}+\mu_{1} Q_{i t}+u_{i t},
$$

where $\mu_{i}$ is the normal value of $(I / K)$ for the $i$ th firm and $u_{i t}$ is an error term. ${ }^{33}$ The term $Q$ represents the value of $q$ at the beginning of the

31. See the original discussions in William C. Brainard and James Tobin, "Pitfalls in Financial Model Building," American Economic Review, vol. 58 (May 1968, Papers and Proceedings, 1967), pp. 99-122; and James Tobin, "A General Equilibrium Approach to Monetary Theory," Journal of Money, Credit and Banking, vol. 1 (February 1969), pp. $15-29$.

32. Andrew Abel and Olivier Blanchard found important roles for profits and output in aggregate investment equations relying on $q$, suggesting problems of aggregation or that alternative sources of finance are not perfect substitutes. Andrew B. Abel and Olivier J. Blanchard, "The Present Value of Profits and Cyclical Movements in Investment," Econometrica, vol. 54 (March 1986), pp. 249-73.

33. The quadratic adjustment cost framework that motivates a linear relationship between the investment-capital ratio and $q$, and the adjustments of $q$ for corporate and personal taxation were developed by Andrew Abel, Lawrence Summers, and Fumio Hayashi. Assume that adjustment costs, $A$, follow: $A_{i t}=\left(2 \mu_{1}\right)^{-1}\left[(I / K)_{i t}-\mu_{i}-u_{i t}\right]^{2} K_{i t}$, if $\left[(I / K)_{i t}-\mu_{i}\right] \geq 0$; and $A_{i t}=0$, otherwise. We also assume that shocks occur during the 
period and is defined as the sum of the value of equity and debt less the value of inventories divided by the replacement cost of the capital stock, adjusted for corporate and personal tax considerations (see Appendix B for details). Estimates based on unadjusted $q$ are very similar.

Table 4 presents estimates of the $Q$ investment model, including cash flow, for each of the three retention classes. The equations were estimated with fixed firm and year effects. ${ }^{34}$ Results are reported over three time periods, 1970-75, 1970-79, and 1970-84. There are two reasons to expect that the sensitivity of investment to cash flow in class 1 will be most pronounced in the shorter periods. First, most class 1 firms (26 out of 49) began paying dividends in the last two years of the sample, and were no longer exhausting all their internal funds. Second, as firms mature and more observations of project realizations and balance sheets are collected, asymmetric information problems should become less severe.

The structure of the Value Line data permits an interesting test of this possibility. A firm is not added to the data base until it is "of interest to subscribers and the financial community." Once a firm is added, however, observations on items from its income statements and balance sheets are collected for at least 10 years prior to the date it is added to the Value Line data base. Most class 1 firms were not recognized until near the end of the sample period even though our data for these firms extend back to $1969 .{ }^{35}$ Therefore the strongest case for asymmetric

period $t$ so that the $Q$ observed by the firm in formulating the capital spending decision is uncorrelated with the unanticipated components of the shocks. Andrew B. Abel, Investment and the Value of Capital (Garland Publishing Company, 1979); Lawrence H. Summers, "Taxation and Corporate Investment: A $q$-Theory Approach," BPEA, 1:1981, pp. 67-127; Fumio Hayashi, "Tobin's Marginal $q$ and Average $q$ : A Neoclassical Interpretation," Econometrica, vol. 50 (January 1982), pp. 213-24.

34. Fixed time effects are included to capture aggregate business-cycle influences. Fixed firm effects account for unobserved time-invariant links between investment and the explanatory variables. That is, the "within" effect of $Q$ or cash flow on investment is captured by our estimates. Problems of high values of average $Q$ stemming from monopoly rents not captured in our formulation will be eliminated by using fixed-effects methods as long as the markup of price over marginal cost is constant over the period. See Eric B. Lindenberg and Stephen A. Ross, "Tobin's $q$ Ratio and Industrial Organization," Journal of Business, vol. 54 (January 1981), pp. 1-32; Michael A. Salinger, "Tobin's q, Unionization, and the Concentration-Profits Relationship," Rand Journal of Economics, vol. 15 (Summer 1984), pp. 159-70.

35. Only 10 of the 49 firms were in the data base as of 1973. By 1980, 29 firms, over half the sample, were yet to be added. We thank Maria Latorraca of Value Line for providing information about the procedure used to add firms to the sample. 
Table 4. Effects of $Q$ and Cash Flow on Investment, Various Periods, 1970-84a

\begin{tabular}{cccc}
\hline $\begin{array}{c}\text { Independent } \\
\text { variable and } \\
\text { summary } \\
\text { statistic }\end{array}$ & Class 1 & Class 2 & Class 3 \\
\hline$Q_{i t}$ & -0.0010 & $1970-75$ & \\
& $(0.0004)$ & 0.0072 & 0.0014 \\
$(C F / K)_{\text {it }}$ & 0.670 & $0.0017)$ & $(0.0004)$ \\
& $(0.044)$ & $(0.075)$ & 0.254 \\
$\bar{R}^{2}$ & 0.55 & 0.19 & $0.022)$ \\
& & $1970-79$ & \\
$Q_{i t}$ & 0.0002 & 0.0060 & 0.0020 \\
& $(0.0004)$ & $(0.0011)$ & $(0.0003)$ \\
$(C F / K)_{i t}$ & 0.540 & 0.313 & 0.185 \\
& $(0.036)$ & $(0.054)$ & $(0.013)$ \\
$\bar{R}^{2}$ & 0.47 & 0.20 & 0.14 \\
& & $1970-84$ & \\
$Q_{i t}$ & 0.0008 & 0.0046 & 0.0020 \\
& $(0.0004)$ & $(0.0009)$ & $(0.0003)$ \\
$(C F / K)_{i t}$ & 0.461 & 0.363 & 0.230 \\
$\bar{R}^{2}$ & $(0.027)$ & $(0.039)$ & $(0.010)$ \\
& 0.46 & 0.28 & 0.19 \\
\hline
\end{tabular}

Source: Authors' estimates of equation 3 based on a sample of firm data from Value Line data base. See text and Appendix B.

a. The dependent variable is the investment-capital ratio $(I / K)_{i t}$, where $I$ is investment in plant and equipment and $K$ is beginning-of-period capital stock. Independent variables are defined as follows: $Q$ is the sum of the value of equity and debt less the value of inventories, divided by the replacement cost of the capital stock adjusted for corporate and personal taxes (see Appendix B); $(C F / K)_{i t}$ is the cash flow-capital ratio. The equations were estimated using fixed firm and year effects (not reported). Standard errors appear in parentheses.

information between firms and outside investors can be made for the shorter time periods, 1970-79 and particularly 1970-75.

The results in table 4 show large estimated cash flow coefficients for firms in class 1 . As expected, the cash flow coefficient is largest $(0.670)$ in the earliest period, when most of these firms had yet to be recognized by Value Line. The coefficient is the smallest (0.461) for 1970-84. Furthermore, as the sample period is extended one year at a time from 1970-75 to 1970-84, the estimated cash flow coefficients for these firms decline monotonically. ${ }^{36}$ The cash flow coefficients in classes 2 and 3 are

36. The coefficients for the periods $1970-75$ through $1970-84$ are: $0.670,0.571,0.566$, $0.554,0.540,0.520,0.510,0.494,0.481$, and 0.461 . The corresponding coefficients for firms in the third class are: $0.254,0.176,0.160,0.173,0.185,0.204,0.217,0.221,0.230$, and 0.230 . The coefficients of firms in class 2 always fall in the middle. 
positive and approximately stable over time. That the cash flow coefficient is different from zero even for the mature firms in class 3 is not surprising given the limitations of the $Q$ model. ${ }^{37}$

It is the difference in the estimated coefficients across classes that we stress. These differences range from 0.416 for $1970-75$ to 0.231 for 1970 84 , the smallest difference for any period in our sample. These differences are always statistically significant at very high confidence levels. The $t$ statistic under the null hypothesis that the class 1 cash flow coefficient equals the class 3 coefficient is 12.1 for the 1970-84 sample period, in which the difference is the smallest. That the difference between the classes narrows as the time period is extended is expected; asymmetric information should not cause permanent differences in investment behavior for ultimately successful firms like the ones in our sample. On the other hand, that the differences remain substantial for so long indicates that the phenomenon is quite persistent. ${ }^{38}$

The model explains a greater proportion of the variance of $I / K$ in class 1 as a result of the inclusion of cash flow. In class 1,46 percent to 55 percent of the variance in $I / K$ is explained, depending on the time period analyzed, primarily due to the variation in cash flow alone. The first column of table 5 presents the $Q$ model estimated without cash flow. Adding cash flow increases the $R^{2}$ by 0.23 for class $1,0.11$ for class 2 , and only 0.08 for class 3 , confirming the greater statistical importance of cash flow for firms in the first class.

Furthermore, the economic significance of these results is reinforced by the high variability of cash flow in the first class. Investment is two to three times more sensitive to cash flow fluctuations in this class than it is in the third, while the underlying variations in cash flow for the first

37. To the extent that firms are experiencing tax losses or are unable to take full advantage of investment incentives, our tax-adjusted $Q$ is mismeasured. A positive coefficient on cash flow in the estimated investment equation could reflect to some extent this mismeasurement of $Q$. Moreover, because of the greater volatility of earnings in firms in class 1 , such firms may be more likely to experience the problem. We did not adjust the tax measures for each firm, but reestimating the models reported in table 4 using unadjusted $q$ produced virtually identical estimated effects of internal cash flow on investment.

38. Because the firms in the first two classes are smaller on average than those in the third, one might expect that these results reflect differences due to size rather than retention practices. But the third class contains many small firms as well. When the sample is split into thirds by firm size, as measured by average capital stock, small firms have relatively low cash flow coefficients. 
Table 5. Effects of $Q$ and Cash Flow on Investment: Consideration of Measurement Error, 1970-84 ${ }^{\text {a }}$

\begin{tabular}{|c|c|c|c|c|c|}
\hline $\begin{array}{l}\text { Independent } \\
\text { variable and } \\
\text { summary } \\
\text { statistic }\end{array}$ & $\begin{array}{l}\text { Ordinary } \\
\quad \text { least } \\
\text { squares }^{\mathrm{b}}\end{array}$ & $\begin{array}{l}\text { Ordinary } \\
\text { least } \\
\text { squares }^{\mathrm{b}} \\
\text { with } \\
(C F / K)\end{array}$ & $\begin{array}{l}\text { Instrumental } \\
\text { variable }^{b, c}\end{array}$ & $\begin{array}{c}\text { First } \\
\text { difference }\end{array}$ & $\begin{array}{c}\text { Second } \\
\text { difference }\end{array}$ \\
\hline$Q_{i t}$ & $\begin{array}{c}0.0045 \\
(0.0004)\end{array}$ & $\begin{array}{c}0.0008 \\
(0.0004)\end{array}$ & $\begin{array}{c}\text { Class 1 } \\
0.0065 \\
(0.0009)\end{array}$ & $\begin{array}{c}-0.0021 \\
(0.0006)\end{array}$ & $\begin{array}{c}-0.0040 \\
(0.0010)\end{array}$ \\
\hline$(C F / K)_{i t}$ & $\ldots$ & $\begin{array}{c}0.464 \\
(0.027)\end{array}$ & $\begin{array}{c}0.455 \\
(0.029)\end{array}$ & $\begin{array}{c}0.496 \\
(0.034)\end{array}$ & $\begin{array}{c}0.457 \\
(0.040)\end{array}$ \\
\hline $\bar{R}^{2}$ & 0.23 & 0.46 & 0.53 & 0.25 & 0.22 \\
\hline$Q_{i t}$ & $\begin{array}{c}0.0073 \\
(0.0009)\end{array}$ & $\begin{array}{c}0.0046 \\
(0.0009)\end{array}$ & $\begin{array}{c}\text { Class 2 } \\
0.0035 \\
(0.0011)\end{array}$ & $\begin{array}{c}0.0106 \\
(0.0015)\end{array}$ & $\begin{array}{c}0.0090 \\
(0.0019)\end{array}$ \\
\hline$(C F / K)_{i t}$ & $\ldots$ & $\begin{array}{c}0.363 \\
(0.039)\end{array}$ & $\begin{array}{c}0.418 \\
(0.038)\end{array}$ & $\begin{array}{c}0.268 \\
(0.046)\end{array}$ & $\begin{array}{c}0.364 \\
(0.054)\end{array}$ \\
\hline $\bar{R}^{2}$ & 0.17 & 0.28 & 0.28 & 0.14 & 0.13 \\
\hline$Q_{i t}$ & $\begin{array}{c}0.0044 \\
(0.0002)\end{array}$ & $\begin{array}{c}0.0020 \\
(0.0003)\end{array}$ & $\begin{array}{l}\text { Class } 3 \\
0.0024 \\
(0.0004)\end{array}$ & $\begin{array}{c}0.0032 \\
(0.0004)\end{array}$ & $\begin{array}{c}0.0036 \\
(0.0005)\end{array}$ \\
\hline$(C F / K)_{i t}$ & $\ldots$ & $\begin{array}{c}0.230 \\
(0.010)\end{array}$ & $\begin{array}{c}0.238 \\
(0.010)\end{array}$ & $\begin{array}{c}0.223 \\
(0.013)\end{array}$ & $\begin{array}{c}0.228 \\
(0.014)\end{array}$ \\
\hline $\bar{R}^{2}$ & 0.11 & 0.19 & 0.19 & 0.08 & 0.07 \\
\hline
\end{tabular}

Source: Same as table 4.

a. Dependent variable is the investment-capital ratio $(I / K)_{i t}$. All variables are as defined in table 4, note a. Standard errors appear in parentheses.

b. Estimated using fixed firm and year effects.

c. The instrumental variable procedure uses lagged $Q$ as an instrument for $Q$.

d. All variables expressed as first differences.

e. All variables expressed as second differences.

class are more than three times larger than those in the third class, measured by the standard deviation of $C F / K$ reported in table 2 .

\section{ALTERNATIVE ESTIMATION METHODS AND SPECIFICATIONS FOR} THE $Q$ MODEL

In this section, we examine the robustness of the results presented to this point for the $Q$ model with respect to changes in estimation technique and specification. There are at least two problems in measuring $Q$ that might affect the econometric results for cash flow. First, to the extent the stock market is excessively volatile, $Q$ may not reflect market fundamentals. Second, the replacement capital stock in $Q$ may be measured with error. The results of tests to deal with these problems are 
reported in table 5. First, using lagged $Q$ as an instrument for $Q$, we obtained similar coefficients on the $Q$ and cash flow terms. ${ }^{39}$ Second, we estimated the model using first differences and second differences (as opposed to the conventional fixed-effects, within-group estimator) to address measurement-error problems; coefficient estimates on cash flow are similar in all cases. ${ }^{40}$

Across all the tests reported in table 5, differences between the class 1 and class 3 cash flow coefficients range between 0.217 and 0.273 . This range is consistent with the difference of 0.231 estimated with the basic $Q$ model over 1970-84. If these tests are run on earlier time periods, the estimated difference in the cash flow effects across classes rises, but the differences remain remarkably consistent across different estimation techniques for a given period. The differences between classes 1 and 3 for 1970-79, for example, range between 0.331 and 0.355 .

Table 6 reports estimates of alternative specifications to analyze further the robustness of the difference in cash flow effects in different retention classes. Results are reported both for 1970-79 and for 197084. Some rejections of the strongest versions of the $q$ theory result from a significant effect of lagged $Q$ in explaining investment. The second model presented in table 6 includes lagged $Q$. In the third class, lagged $Q$ does have a statistically significant estimated coefficient, and the coefficient on the current $Q$ variable becomes positive in the first class when lagged $Q$ is included. The pattern of cash flow coefficients across classes for both time periods, which is the result of primary interest here, is virtually identical when lagged $Q$ is included in the equation. ${ }^{41}$

We also report the effect of including additional lags of cash flow in table 6. Lagged values of cash flow may have explanatory power for

39. This finding also addressed the concern of Fumio Hayashi and Tohru Inoue that disturbances in the cost of adjustment function are incorporated into the beginning-ofperiod $Q$, making $Q$ endogenous. Fumio Hayashi and Tohru Inoue, "Implementing the $\mathrm{Q}$ Theory of Investment in Micro Data: Japanese Manufacturing, 1977-1985" (Osaka University, June 1987).

40. Zvi Griliches and Jerry Hausman argue that measurement error will lead to different biases across potential estimators that are similar in that they control for firm-specific effects, but differ in their signal-to-noise ratios, making it possible to place bounds on the importance of measurement error. Zvi Griliches and Jerry A. Hausman, "Errors in Variables in Panel Data," Journal of Econometrics, vol. 31 (February 1986), pp. 93-118.

41. We also considered the possibility that the adjustment cost function was nonlinear by adding $Q^{2}$ to the equations. This change did not materially affect the cash flow coefficient pattern. 
Table 6. Effects of $Q$ and Cash Flow on Investment: Alternative Specifications, Various Periods, 1970-84 ${ }^{a}$

\begin{tabular}{|c|c|c|c|c|c|c|}
\hline \multirow{2}{*}{$\begin{array}{c}\text { Independent } \\
\text { variable } \\
\text { and } \\
\text { summary } \\
\text { statistic }\end{array}$} & \multicolumn{2}{|c|}{ Class 1} & \multicolumn{2}{|c|}{ Class 2} & \multicolumn{2}{|c|}{ Class 3} \\
\hline & $1970-79$ & $1970-84$ & $1970-79$ & $1970-84$ & $1970-79$ & $1970-84$ \\
\hline & \multicolumn{6}{|c|}{ Model with additional cash flow lags } \\
\hline$Q_{i t}$ & $\begin{array}{c}-0.0002 \\
(0.0004)\end{array}$ & $\begin{array}{c}0.0007 \\
(0.0004)\end{array}$ & $\begin{array}{c}0.0059 \\
(0.0011)\end{array}$ & $\begin{array}{c}0.0044 \\
(0.0009)\end{array}$ & $\begin{array}{c}0.0011 \\
(0.0003)\end{array}$ & $\begin{array}{c}0.0011 \\
(0.0003)\end{array}$ \\
\hline$(C F / K)_{i t}$ & $\begin{array}{c}0.508 \\
(0.035)\end{array}$ & $\begin{array}{c}0.400 \\
(0.029)\end{array}$ & $\begin{array}{c}0.245 \\
(0.059)\end{array}$ & $\begin{array}{c}0.304 \\
(0.045)\end{array}$ & $\begin{array}{c}0.146 \\
(0.015)\end{array}$ & $\begin{array}{c}0.168 \\
(0.012)\end{array}$ \\
\hline$(C F / K)_{i, t-1}$ & $\begin{array}{c}0.216 \\
(0.045)\end{array}$ & $\begin{array}{c}0.167 \\
(0.039)\end{array}$ & $\begin{array}{c}0.100 \\
(0.062)\end{array}$ & $\begin{array}{c}0.095 \\
(0.053)\end{array}$ & $\begin{array}{c}0.092 \\
(0.021)\end{array}$ & $\begin{array}{c}0.116 \\
(0.018)\end{array}$ \\
\hline$(C F / K)_{i, t-2}$ & $\begin{array}{c}0.179 \\
(0.043)\end{array}$ & $\begin{array}{c}0.115 \\
(0.037)\end{array}$ & $\begin{array}{c}0.132 \\
(0.063)\end{array}$ & $\begin{array}{c}0.073 \\
(0.052)\end{array}$ & $\begin{array}{c}0.116 \\
(0.020)\end{array}$ & $\begin{array}{c}0.074 \\
(0.017)\end{array}$ \\
\hline $\bar{R}^{2}$ & 0.54 & 0.49 & 0.23 & 0.30 & 0.16 & 0.21 \\
\hline \multicolumn{7}{|c|}{ Model including lagged $Q$} \\
\hline$Q_{i t}$ & $\begin{array}{c}0.0037 \\
(0.0015)\end{array}$ & $\begin{array}{c}0.0033 \\
(0.0013)\end{array}$ & $\begin{array}{c}0.0064 \\
(0.0016)\end{array}$ & $\begin{array}{c}0.0052 \\
(0.0014)\end{array}$ & $\begin{array}{c}0.0014 \\
(0.0004)\end{array}$ & $\begin{array}{c}0.0015 \\
(0.0004)\end{array}$ \\
\hline$Q_{i, t-1}$ & $\begin{array}{c}0.0011 \\
(0.0006)\end{array}$ & $\begin{array}{c}0.0015 \\
(0.0006)\end{array}$ & $\begin{array}{c}0.0004 \\
(0.0015)\end{array}$ & $\begin{array}{r}-0.0002 \\
(0.0013)\end{array}$ & $\begin{array}{c}0.0011 \\
(0.0004)\end{array}$ & $\begin{array}{c}0.0008 \\
(0.0003)\end{array}$ \\
\hline$(C F / K)_{i t}$ & $\begin{array}{c}0.528 \\
(0.041)\end{array}$ & $\begin{array}{c}0.426 \\
(0.030)\end{array}$ & $\begin{array}{c}0.287 \\
(0.059)\end{array}$ & $\begin{array}{c}0.345 \\
(0.041)\end{array}$ & $\begin{array}{c}0.183 \\
(0.014)\end{array}$ & $\begin{array}{c}0.225 \\
(0.010)\end{array}$ \\
\hline $\bar{R}^{2}$ & 0.58 & 0.53 & 0.22 & 0.29 & 0.14 & 0.20 \\
\hline
\end{tabular}

Source: Same as table 4.

a. Dependent variable is the investment-capital ratio $(I / K)_{i t}$. All variables are as defined in table 4 , note a. Equations are estimated with fixed firm and year effects (not reported). Standard errors appear in parentheses.

investment in a time-to-build context, for example. Collinearity among the cash flow variables reduces the current cash flow coefficient in all classes when additional lags are included, but the pattern across classes remains clear. Indeed, the differences between the current cash flow coefficients in the classes 1 and 3 are almost identical to the differences between the current cash flow coefficients in table 4 . The differences in the sums of the cash flow coefficients between the first and third classes rise substantially when more lags are added. ${ }^{42}$ Also the current cash flow coefficient relative to the lagged coefficients is much larger for class 1 than for class 3 . To the extent that the difference in the cash flow effects across classes reflects the impact of financial constraints on investment,

42. The $t$-statistic for the null hypothesis that the sum of the cash flow coefficients is equal across the first and third classes is 10.6. When a third lag of cash flow was included in the equation, its coefficient was not significantly different from zero at the 10 percent level in any of the classes. 
one would expect the difference to be most evident in the coefficient on current cash flow, especially because these data are annual. ${ }^{43}$ The effects of the lagged coefficients may well reflect shortcomings in the empirical performance of $Q$. That the estimated coefficient on $Q$ for the mature firms in class 3 is only half as large when longer lags on cash flow are included supports this interpretation.

A different interpretation of the effect of cash flow on investment is that movements in cash flow reflect productivity shocks not captured in the beginning-of-period $Q$ (that is, cash flow may be correlated with the disturbance in the adjustment cost function). To explain our results, one would have to account for the different effect of productivity shocks in firms grouped only by their retention behavior. From a broader perspective, it is also possible that current cash flow contains "news" about investment opportunities not captured in the beginning-of-period $Q$. To address these points, we reestimated the basic $Q$ model in two ways, first treating $C F / K$ as endogenous and using instrumental variables techniques and then adding $Q$ dated at the end of the current periodthat is, incorporating all news arriving in the current period-to the ordinary least squares model. With both alterations, the differences in the estimated cash flow coefficients across classes remained. ${ }^{44}$

In summary, the results presented here suggest important effects of fluctuations in the availability of internal finance on investment. Internal funds help explain investment in all classes, even for firms that have much more cash flow than investment. Most likely, that finding indicates the pitfalls in using average $Q$ in empirical studies. For our purposes, however, the fundamental finding is the substantial difference across classes in the effect of cash flow on investment. Several possible issues involving measurement error have been addressed by instrumenting $Q$ and estimating the basic model with first and second differences. We have also considered several alternative specifications, including lagged $Q$, additional lags of cash flow, and treating cash flow as endogenous.

43. Abel and Blanchard consider three quarterly lags of profits in a $q$ model estimated from aggregate data for the manufacturing sector. This time period falls within our contemporaneous annual observation. Abel and Blanchard found only the coefficient on the first lag of profits to be statistically significantly different from zero. Abel and Blanchard, "The Present Value of Profits and Investment."

44. The difference in the effect of cash flow across classes generally widened when current cash flow was instrumented with lagged variables. This result also suggests that the possible dependence of current cash flow on current investment is not responsible for the observed pattern of cash flow coefficients. 
In all these models, the estimated difference in cash flow effects in the different retention classes is always statistically significant at very high confidence levels. Furthermore, the estimated differentials are larger over shorter periods when the firms in class 1 are less mature and probably face more severe asymmetric information problems. The results over shorter periods are also remarkably consistent across the various models and estimation techniques. For example, the differential for 1970-79 between the estimated cash flow coefficients for classes 1 and 3 was between 0.33 and 0.38 over all the tests reported in tables 4 through 6 . The range for $1970-75$ was 0.36 to 0.42 . These results are consistent with the cost differential between internal and external finance predicted by the models described earlier and with the differences in the $q$ values we found across classes. The economic importance of these findings is magnified by the fact that cash flow is highly variable for the rapidly growing firms in the first class, while mature firms in the third class experience much less variation in cash flow.

Because the firms we examine, even the rapidly growing firms in class 1 , are large manufacturing corporations by economywide standards, the significance of internal finance for capital spending may well be greater for smaller companies, which may have more difficult, or no, access to centralized securities markets.

\section{SALES ACCELERATOR INVESTMENT DEMAND MODELS}

From a theoretical standpoint, the $Q$ investment demand model has many attractive features. In practice, however, other approaches have performed better empirically. Some of the most successful empirical investment models are based on the traditional acceleration principle, which links the demand for capital goods to the level or change in a firm's output or sales. ${ }^{45}$ Below we test whether the pattern of cash flow effects across retention classes holds up in models that include sales. Certainly one possible explanation for the effect of the cash flow variables in all the retention classes is that internal finance is correlated with sales.

45. Traditional accelerator models are based on the change in sales rather than its level. For a given number of lags, this approach imposes one restriction on the estimated coefficients. In a recent paper, Abel and Blanchard present an accelerator model that includes delivery and installation lags. In this more general approach, estimating the model with levels of sales is appropriate. Andrew Abel and Olivier Blanchard, "Investment and Sales: Some Empirical Evidence,” Working Paper 2050 (NBER, October 1986). 
Table 7 presents estimated equations for the three retention classes that include cash flow and current and lagged values of sales. Two equations are reported, one that includes only sales variables augmented by cash flow and one that adds $Q$. Most of the sales terms are statistically significant individually, and they are highly significant jointly. Moreover, some of the cash flow effects in the $Q$ model can indeed be explained by the correlation of cash flow and sales; the cash flow coefficients decline in all three classes when the sales variables are added to the equation. This may indicate discrepancies between average and marginal $Q$ or accelerator effects. The pattern of the cash flow coefficients across classes, however, remains about the same as in the models without sales. The results in table 7 are for the full 1970-84 period; greater estimated differences in the cash flow coefficients arise for shorter sample periods. The different effects of cash flow between the classes 1 and 3 for all sample periods are similar to the results obtained from the $Q$ model without sales. These results show that including sales variables does not change the primary result presented above.

The results for the equation that includes $Q$ also provide an interesting perspective on a point often raised in the investment literature. It is typical to find significant effects of both sales and profits or cash flow in an investment equation. In that case, however, the question remains whether the cash flow variable should be interpreted as a signal of the profitability of investment not captured in the simple accelerator formulation, or whether the significance of cash flow arises because it represents an additional supply of low-cost investment finance for firms that must pay a premium for external funds.

Including $Q$ in the estimated equation helps to resolve this question. Because $Q$ is based on asset prices determined in forward-looking markets, it should capture the prospective profitability of investment better than lags of past profits. The results show that including $Q$ reduces the cash flow effect somewhat in classes 2 and 3, but cash flow still has a strong effect in all the dividend-payout classes. To the extent that $Q$ captures the effect of future profitability on the demand for investment, this result supports the financing constraint interpretation. Again, that the cash flow effect remains significant in the class of high-payout firms suggests caution in this regard. The difference in cash flow effects across classes remains the strongest evidence supporting the finance constraint view. 
Table 7. Effects of Sales and Cash Flow on Investment, 1970-84 ${ }^{\mathrm{a}}$

\begin{tabular}{|c|c|c|c|}
\hline $\begin{array}{l}\text { Independent } \\
\text { variable and } \\
\text { summary } \\
\text { statistic }\end{array}$ & Class I & Class 2 & Class 3 \\
\hline \multicolumn{4}{|c|}{ Model with sales-capital ratio } \\
\hline$(C F / K)_{i t}$ & $\begin{array}{c}0.277 \\
(0.033)\end{array}$ & $\begin{array}{c}0.256 \\
(0.047)\end{array}$ & $\begin{array}{c}0.120 \\
(0.013)\end{array}$ \\
\hline$(S / K)_{i t}$ & $\begin{array}{c}0.041 \\
(0.007)\end{array}$ & $\begin{array}{c}0.045 \\
(0.009)\end{array}$ & $\begin{array}{c}0.027 \\
(0.002)\end{array}$ \\
\hline$(S / K)_{i, t-1}$ & $\begin{array}{r}-0.015 \\
(0.011)\end{array}$ & $\begin{array}{r}-0.016 \\
(0.011)\end{array}$ & $\begin{array}{c}-0.001 \\
(0.003)\end{array}$ \\
\hline$(S / K)_{i, t-2}$ & $\begin{array}{c}0.031 \\
(0.012)\end{array}$ & $\begin{array}{c}0.015 \\
(0.011)\end{array}$ & $\begin{array}{c}0.008 \\
(0.003)\end{array}$ \\
\hline$(S / K)_{i, t-3}$ & $\begin{array}{r}-0.036 \\
(0.009)\end{array}$ & $\begin{array}{r}-0.020 \\
(0.008)\end{array}$ & $\begin{array}{c}-0.010 \\
(0.003)\end{array}$ \\
\hline $\bar{R}^{2}$ & 0.54 & 0.30 & 0.23 \\
\hline \multicolumn{4}{|c|}{ Model with sales-capital ratio and $Q$} \\
\hline$Q_{i t}$ & $\begin{array}{r}-0.0004 \\
(0.0004)\end{array}$ & $\begin{array}{c}0.0049 \\
(0.0009)\end{array}$ & $\begin{array}{c}0.0019 \\
(0.0003)\end{array}$ \\
\hline$(C F / K)_{i t}$ & $\begin{array}{c}0.286 \\
(0.035)\end{array}$ & $\begin{array}{c}0.178 \\
(0.047)\end{array}$ & $\begin{array}{c}0.086 \\
(0.013)\end{array}$ \\
\hline$(S / K)_{i t}$ & $\begin{array}{c}0.042 \\
(0.007)\end{array}$ & $\begin{array}{c}0.047 \\
(0.009)\end{array}$ & $\begin{array}{c}0.029 \\
(0.002)\end{array}$ \\
\hline$(S / K)_{i, t-1}$ & $\begin{array}{r}-0.013 \\
(0.011)\end{array}$ & $\begin{array}{r}-0.021 \\
(0.011)\end{array}$ & $\begin{array}{c}-0.003 \\
(0.003)\end{array}$ \\
\hline$(S / K)_{i, t-2}$ & $\begin{array}{c}0.029 \\
(0.012)\end{array}$ & $\begin{array}{c}0.015 \\
(0.011)\end{array}$ & $\begin{array}{c}0.008 \\
(0.003)\end{array}$ \\
\hline$(S / K)_{i, t-3}$ & $\begin{array}{r}-0.036 \\
(0.009)\end{array}$ & $\begin{array}{r}-0.012 \\
(0.008)\end{array}$ & $\begin{array}{r}-0.009 \\
(0.003)\end{array}$ \\
\hline $\bar{R}^{2}$ & 0.54 & 0.34 & 0.24 \\
\hline
\end{tabular}

Source: Authors' calculations based on a sample of firm data from Value Line data base. See text description and Appendix B.

a. The dependent variable is the investment-capital ratio $(I / K)_{i t}$ defined as in table 4 , note a. $Q$ and $(C F / K)_{i t}$ are also as defined in table 4 , note a. $(S / K)_{i t}$ is the ratio of sales, $S$, to the beginning-of-period capital stock. All equations were estimated with fixed time and firm effects (not reported). Standard errors appear in parentheses.

INTERNAL FINANCE IN THE NEOCLASSICAL INVESTMENT MODEL

A common criticism of the sales accelerator model is that it does not incorporate the relative price of capital or capital services in the empirical specification. This issue is addressed by the neoclassical investment 
model pioneered by Jorgenson. ${ }^{46}$ In its most general form, the neoclassical model is derived from the solution to a dynamic factor demand problem that determines the firm's optimal level of capital services through time. The change in the demand for capital services along with the depreciation of existing capital determines investment.

With perfectly competitive input and output markets, the firm's optimal demand for capital services depends ultimately on the price of output and the relative prices of various inputs, including the cost of capital. To simplify the empirical specification, however, Jorgenson used a transformation of the reduced form of the optimal demand for capital based on a Cobb-Douglas production function. The transformation allows the demand for capital to be expressed as a function of the relative cost of capital services alone; the effect of other factor prices is captured by including the level of output or sales in the model. In this case, the neoclassical model with partial-adjustment assumptions takes a form similar to the accelerator model, except that the sales or output term is modified by a cost of capital measure. If firms have Cobb-Douglas production functions, the desired capital stock is proportional to the ratio of sales to the tax-adjusted relative price of capital. ${ }^{47}$ This variable is denoted by $J$ in table 8 .

The first equation in table 8 includes the cost of capital and cash flow variables. Again, the pattern of coefficients across the retention classes shows that cash flow has a substantially higher effect for firms that pay low dividends than for mature, high-payout firms. The neoclassical model is subject to the same criticism that is raised against the accelerator model: the equation is specified with backward-looking variables. However, adding tax-adjusted $Q$ to the equation, as we do in the second equation reported in table 8 , does not change the results substantially.

Though not reported here, we have also estimated the investment equations outlined before with instrumental variables for $Q$, cash flow, and sales to attempt to correct for "news" in cash flow and measurement error problems. The results depend on the specific instruments used,

46. For a survey of much of the relevant literature, see Dale W. Jorgenson, "Econometric Studies of Investment Behavior: A Survey," Journal of Economic Literature, vol. 9 (December 1971), pp. 1111-47; and Clark, "Investment in the 1970s."

47. The general form of the tax adjustments to cost of capital we use in the empirical work presented here is based on the original development by Hall and Jorgenson, "Tax Policy." The cost of capital definition is presented in Appendix B. 
Steven M. Fazzari, R. Glenn Hubbard, and Bruce C. Petersen

Table 8. Effects of Cost of Capital and Cash Flow on Investment, 1970-84 ${ }^{\mathrm{a}}$

\begin{tabular}{|c|c|c|c|}
\hline $\begin{array}{l}\text { Independent } \\
\text { variable and } \\
\text { summary } \\
\text { statistic }\end{array}$ & Class 1 & Class 2 & Class 3 \\
\hline \multicolumn{4}{|c|}{ Model with adjusted sales-cost of capital ratio } \\
\hline$(C F / K)_{i t}$ & $\begin{array}{c}0.337 \\
(0.029)\end{array}$ & $\begin{array}{c}0.331 \\
(0.043)\end{array}$ & $\begin{array}{c}0.199 \\
(0.011)\end{array}$ \\
\hline$(J / K)_{i t}$ & $\begin{array}{c}0.273 \\
(0.043)\end{array}$ & $\begin{array}{c}0.177 \\
(0.039)\end{array}$ & $\begin{array}{c}0.081 \\
(0.009)\end{array}$ \\
\hline$(J / K)_{i, t-1}$ & $\begin{array}{c}-0.100 \\
(0.072)\end{array}$ & $\begin{array}{r}-0.070 \\
(0.055)\end{array}$ & $\begin{array}{r}-0.023 \\
(0.012)\end{array}$ \\
\hline$(J / K)_{i, t-2}$ & $\begin{array}{c}0.152 \\
(0.079)\end{array}$ & $\begin{array}{c}0.046 \\
(0.057)\end{array}$ & $\begin{array}{c}0.025 \\
(0.013)\end{array}$ \\
\hline$(J / K)_{i, t-3}$ & $\begin{array}{r}-0.123 \\
(0.060)\end{array}$ & $\begin{array}{r}-0.069 \\
(0.044)\end{array}$ & $\begin{array}{c}0.002 \\
(0.010)\end{array}$ \\
\hline $\bar{R}^{2}$ & 0.52 & 0.28 & 0.20 \\
\hline \multicolumn{4}{|c|}{ Model with adjusted sales-cost of capital ratio and $Q$} \\
\hline$Q_{i t}$ & $\begin{array}{c}0.0005 \\
(0.0004)\end{array}$ & $\begin{array}{c}0.0050 \\
(0.0009)\end{array}$ & $\begin{array}{c}0.0020 \\
(0.0003)\end{array}$ \\
\hline$(C F / K)_{i t}$ & $\begin{array}{c}0.319 \\
(0.033)\end{array}$ & $\begin{array}{c}0.248 \\
(0.044)\end{array}$ & $\begin{array}{c}0.163 \\
(0.011)\end{array}$ \\
\hline$(J / K)_{i t}$ & $\begin{array}{c}0.275 \\
(0.043)\end{array}$ & $\begin{array}{c}0.190 \\
(0.038)\end{array}$ & $\begin{array}{c}0.086 \\
(0.009)\end{array}$ \\
\hline$(J / K)_{i, t-1}$ & $\begin{array}{r}-0.114 \\
(0.073)\end{array}$ & $\begin{array}{r}-0.090 \\
(0.053)\end{array}$ & $\begin{array}{r}-0.030 \\
(0.012)\end{array}$ \\
\hline$(J / K)_{i, t-2}$ & $\begin{array}{c}0.158 \\
(0.079)\end{array}$ & $\begin{array}{c}0.051 \\
(0.055)\end{array}$ & $\begin{array}{c}0.026 \\
(0.012)\end{array}$ \\
\hline$(J / K)_{i, t-3}$ & $\begin{array}{r}-0.125 \\
(0.060)\end{array}$ & $\begin{array}{r}-0.037 \\
(0.043)\end{array}$ & $\begin{array}{c}0.003 \\
(0.010)\end{array}$ \\
\hline $\bar{R}^{2}$ & 0.53 & 0.32 & 0.21 \\
\hline
\end{tabular}

Source: Same as table 7.

a. The equations are as specified in table 7 except that the sales term used in table 7 is modified by a cost of capital measure (see text). The variable, defined $J$, enters the equations above as a ratio to the capital stock at the beginning of the period, $K$. All equations were estimated with fixed time and firm effects (not reported). Standard errors appear in parentheses.

but several general features of the estimates are clear. First, the pattern of declining cash flow coefficients as one moves to the higher payout classes remains. The differential between classes 1 and 3 is generally at least as large as in the reported results. Second, the cash flow effects in class 3 remain as large as or larger than in the OLS/fixed-effect equations. Therefore, no simple correction for measurement error resolves the puzzle of why cash flow has a persistent effect for mature firms in each of the alternative specifications of investment demand we examined. 
Regardless of the conclusion reached about the source of cash flow effects in mature firms, however, the difference in the cash flow effects reported here establishes that firm heterogeneity is an important aspect of the link between finance and real investment.

INVESTMENT EQUATIONS AT THE INDUSTRY LEVEL

Another dimension of firm heterogeneity that may be important for investment behavior is differences across industry categories. Table 9 provides estimates of the basic $Q$ model augmented with cash flow by retention class for several two-digit Standard Industrial Classification (SIC) code manufacturing industry categories. The results reported are robust to the alternative investment demand specifications reviewed before. The number of observations in classes 1 and 2 is small in the separate industry categories. We have reported estimates for these two classes combined for individual two-digit industries that have at least five firms in the combined class. For comparison, we also report the estimated coefficients for the model from a sample that combines the remaining two-digit industries.

In six out of the seven cases, the cash flow effect is larger for the highretention classes than for the more mature firms in class 3 . That the effect of cash flow on investment is greatest for low-payout firms, with industry effects held constant, casts further doubt on a productivity shock interpretation of the differential effect. Because of the small samples, the differentials vary substantially. The one case (chemicals, industry 28) in which the cash flow coefficient for the third class is higher than that for the first two classes has only two firms from the first class, the lowest number for any industry group. These results indicate that greater sensitivity of investment to cash flow in high-retention firms is not a phenomenon restricted to particular industries. The high-technology computer firms in industry 36 have a high differential, for example, but the differential in the food-processing firms in industry 20 is even greater.

BALANCE SHEETS, INTERNAL FINANCE, AND INVESTMENT

The results presented to this point have examined how changes in the flow of internal funds affect investment spending in different kinds of 
Table 9. Effects of $Q$ and Cash Flow on Investment, Various Industries, 1970-84

\begin{tabular}{|c|c|c|c|c|c|c|c|}
\hline \multirow[b]{2}{*}{ Industry } & \multirow{2}{*}{$\begin{array}{c}\text { Standard } \\
\text { Industrial } \\
\text { Classifi- } \\
\text { cation } \\
\text { code }\end{array}$} & \multicolumn{3}{|c|}{ Classes 1 and 2} & \multicolumn{3}{|c|}{ Class 3} \\
\hline & & $Q$ & $C F / K$ & $\bar{R}^{2}$ & $Q$ & $C F / K$ & $\bar{R}^{2}$ \\
\hline Food & 20 & $\begin{array}{r}-0.003 \\
(0.008)\end{array}$ & $\begin{array}{c}0.613 \\
(0.135)\end{array}$ & 0.19 & $\begin{array}{c}0.007 \\
(0.002)\end{array}$ & $\begin{array}{c}0.247 \\
(0.054)\end{array}$ & 0.14 \\
\hline Chemicals & 28 & $\begin{array}{c}0.006 \\
(0.001)\end{array}$ & $\begin{array}{c}0.190 \\
(0.068)\end{array}$ & 0.36 & $\begin{array}{r}-0.001 \\
(0.001)\end{array}$ & $\begin{array}{c}0.413 \\
(0.036)\end{array}$ & 0.28 \\
\hline $\begin{array}{l}\text { Machinery, except } \\
\text { electrical }\end{array}$ & 35 & $\begin{array}{c}0.000 \\
(0.001)\end{array}$ & $\begin{array}{c}0.545 \\
(0.041)\end{array}$ & 0.59 & $\begin{array}{c}0.014 \\
(0.002)\end{array}$ & $\begin{array}{c}0.280 \\
(0.039)\end{array}$ & 0.42 \\
\hline $\begin{array}{l}\text { Electrical and elec- } \\
\text { tronic machinery }\end{array}$ & 36 & $\begin{array}{c}0.002 \\
(0.001)\end{array}$ & $\begin{array}{c}0.293 \\
(0.045)\end{array}$ & 0.21 & $\begin{array}{c}0.000 \\
(0.001)\end{array}$ & $\begin{array}{c}0.207 \\
(0.022)\end{array}$ & 0.27 \\
\hline Transportation & 37 & $\begin{array}{c}0.008 \\
(0.002)\end{array}$ & $\begin{array}{c}0.401 \\
(0.053)\end{array}$ & 0.62 & $\begin{array}{c}0.019 \\
(0.003)\end{array}$ & $\begin{array}{c}0.161 \\
(0.054)\end{array}$ & 0.27 \\
\hline Measuring instruments & 38 & $\begin{array}{c}0.006 \\
(0.002)\end{array}$ & $\begin{array}{c}0.457 \\
(0.108)\end{array}$ & 0.29 & $\begin{array}{c}0.003 \\
(0.001)\end{array}$ & $\begin{array}{c}0.349 \\
(0.047)\end{array}$ & 0.47 \\
\hline All others & & $\begin{array}{c}0.011 \\
(0.003)\end{array}$ & $\begin{array}{c}0.394 \\
(0.056)\end{array}$ & 0.34 & $\begin{array}{c}0.003 \\
(0.001)\end{array}$ & $\begin{array}{c}0.191 \\
(0.017)\end{array}$ & 0.14 \\
\hline
\end{tabular}

Source: Same as table 4.

a. For each industry the equations are exactly the same as the equations in table 4 , except that the firms in classes 1 and 2 are aggregated. All equations were estimated with fixed firm and year effects (not reported). Standard errors are in parentheses.

firms. Of course, stock measures of a firm's internal liquidity might also have an effect on investment for firms that face high costs of external funds due to information problems in capital markets. Cash and marketable securities provide a low-cost source of investment finance for firms that must pay a premium for external funds. To the extent that such firms have accumulated liquid resources, they have a financial cushion that may reduce the sensitivity of their investment to cash flow fluctuations. Therefore, one might expect to observe a positive effect of stock measures of liquidity for the high-retention firms, whose investment is especially sensitive to fluctuations in cash flow.

The motivation for this test is analogous to considerations of precautionary saving. If managers know that they will have to pay a premium for external funds, they should accumulate a stock of liquid assets when cash flow is high. That stock of liquid assets will help smooth investment over downturns and spare firms the need to obtain potentially costly capital from external sources. It might also provide the necessary collateral to obtain new debt as suggested by some of the models considered earlier. Finally, as discussed, debt finance may entail cove- 
Table 10. Effect of Balance Sheet Variables on Investment, 1970-84a

\begin{tabular}{|c|c|c|c|}
\hline $\begin{array}{l}\text { Independent } \\
\text { variable and } \\
\text { summary } \\
\text { statistic }\end{array}$ & Class 1 & Class 2 & Class 3 \\
\hline & \multicolumn{3}{|c|}{ Model including cash and equivalents variable } \\
\hline$Q_{i t}$ & $\begin{array}{c}0.0001 \\
(0.0004)\end{array}$ & $\begin{array}{c}0.0045 \\
(0.0009)\end{array}$ & $\begin{array}{c}0.0019 \\
(0.0003)\end{array}$ \\
\hline$(C F / K)_{i t}$ & $\begin{array}{c}0.372 \\
(0.027)\end{array}$ & $\begin{array}{c}0.348 \\
(0.039)\end{array}$ & $\begin{array}{c}0.224 \\
(0.011)\end{array}$ \\
\hline$(C A S H / K)_{i t}$ & $\begin{array}{c}0.112 \\
(0.011)\end{array}$ & $\begin{array}{c}0.052 \\
(0.020)\end{array}$ & $\begin{array}{c}0.010 \\
(0.007)\end{array}$ \\
\hline \multirow[t]{2}{*}{$\bar{R}^{2}$} & 0.53 & 0.30 & 0.19 \\
\hline & \multicolumn{3}{|c|}{ Model including working capital } \\
\hline$Q_{i t}$ & $\begin{array}{c}0.0003 \\
(0.0004)\end{array}$ & $\begin{array}{c}0.0043 \\
(0.0009)\end{array}$ & $\begin{array}{c}0.0021 \\
(0.0003)\end{array}$ \\
\hline$(C F / K)_{i t}$ & $\begin{array}{c}0.365 \\
(0.030)\end{array}$ & $\begin{array}{c}0.351 \\
(0.039)\end{array}$ & $\begin{array}{c}0.230 \\
(0.010)\end{array}$ \\
\hline$(W C M I / K)_{i t}$ & $\begin{array}{c}0.077 \\
(0.011)\end{array}$ & $\begin{array}{c}0.021 \\
(0.015)\end{array}$ & $\begin{array}{c}-0.011 \\
(0.006)\end{array}$ \\
\hline \multirow[t]{2}{*}{$\bar{R}^{2}$} & 0.51 & 0.29 & 0.19 \\
\hline & \multicolumn{3}{|c|}{$\begin{array}{c}\text { Model including current and lagged values } \\
\text { of cash and sales }\end{array}$} \\
\hline$Q_{i t}$ & $\begin{array}{r}-0.0005 \\
(0.0004)\end{array}$ & $\begin{array}{c}0.0042 \\
(0.0009)\end{array}$ & $\begin{array}{c}0.0012 \\
(0.0003)\end{array}$ \\
\hline$(C A S H / K)_{i t}$ & $\begin{array}{c}0.099 \\
(0.011)\end{array}$ & $\begin{array}{c}0.058 \\
(0.020)\end{array}$ & $\begin{array}{c}0.000 \\
(0.008)\end{array}$ \\
\hline$(C F / K)_{i t}$ & $\begin{array}{c}0.163 \\
(0.036)\end{array}$ & $\begin{array}{c}0.119 \\
(0.054)\end{array}$ & $\begin{array}{c}-0.005 \\
(0.016)\end{array}$ \\
\hline$(C F / K)_{i, t-1}$ & $\begin{array}{c}0.168 \\
(0.044)\end{array}$ & $\begin{array}{c}0.089 \\
(0.061)\end{array}$ & $\begin{array}{c}0.153 \\
(0.022)\end{array}$ \\
\hline$(C F / K)_{i, t-2}$ & $\begin{array}{c}0.071 \\
(0.047)\end{array}$ & $\begin{array}{c}0.002 \\
(0.059)\end{array}$ & $\begin{array}{c}0.091 \\
(0.020)\end{array}$ \\
\hline$(S / K)_{i t}$ & $\begin{array}{c}0.044 \\
(0.007)\end{array}$ & $\begin{array}{c}0.053 \\
(0.009)\end{array}$ & $\begin{array}{c}0.038 \\
(0.003)\end{array}$ \\
\hline$(S / K)_{i, t-1}$ & $\begin{array}{c}-0.035 \\
(0.012)\end{array}$ & $\begin{array}{c}-0.032 \\
(0.012)\end{array}$ & $\begin{array}{c}-0.017 \\
(0.004)\end{array}$ \\
\hline$(S / K)_{i, t-2}$ & $\begin{array}{c}0.026 \\
(0.014)\end{array}$ & $\begin{array}{c}0.018 \\
(0.012)\end{array}$ & $\begin{array}{c}0.001 \\
(0.004)\end{array}$ \\
\hline$(S / K)_{i, t-3}$ & $\begin{array}{c}-0.020 \\
(0.010)\end{array}$ & $\begin{array}{c}-0.015 \\
(0.009)\end{array}$ & $\begin{array}{c}-0.005 \\
(0.003)\end{array}$ \\
\hline $\bar{R}^{2}$ & 0.60 & 0.35 & 0.26 \\
\hline
\end{tabular}

Source: Same as table 7.

a. The dependent variable is the investment-capital ratio $(I / K)_{i t}$, where $I$ is investment in plant and equipment and $K$ is beginning-of-period capital stock. $Q_{i t}$ is the sum of the value of equity and debt less the value of inventories, divided by the replacement cost of the capital stock adjusted for corporate and personal taxes (see Appendix B) $(C F / K)_{i t}$ is the cash flow-capital ratio; $(S / K)_{i t}$ is the ratio of sales to capital; $C A S H$ is cash on hand plus liquid securities; and WCMI is working capital less the book value of inventories. Standard errors appear in parentheses. 
nants and restrictions that constrain firms' ability to use stocks of liquidity. Thus, when financially constrained firms experience increased liquidity, they may be able to finance increased investment.

On the other hand, mature firms that pay a substantial portion of their income as dividends are unlikely to derive any particular benefit for investment from higher stocks of liquid assets. If retained earnings fall below the level necessary to finance desired investment in these firms, they could reduce dividends, or, if managers perceive dividend cuts as negative signals to the market, they could likely obtain relatively lowcost funds from external capital markets. Therefore, one would expect little estimated significance for stock measures of liquidity in the investment of the high-dividend firms in our third class.

Table 10 reports the results of including stock liquidity measures in an augmented $Q$ investment equation similar to the equations presented earlier. We used two alternative liquidity stock variables-cash and equivalents (defined as cash on hand plus securities readily convertible into cash), $C A S H$, and working capital less the book value of inventories, $W C M I$, where working capital is defined as current assets minus current liabilities. Both variables were measured at the beginning of the period and were deflated by the firm's capital stock. The results clearly support the view that changes in balance sheet positions and liquidity have a significant effect on investment for the low-payout firms. On the other hand, the estimated coefficients on the liquidity variables are not statistically different from zero for the mature firms. The results for the firms in class 2 fall in the middle. These results are also remarkably robust in equations that include sales accelerator variables (not reported here). As discussed, the cash flow coefficients drop for all the classes when lags of sales are included. The coefficients on the stock liquidity variables, however, are virtually identical in models that include sales. Similar results were obtained when we included current assets alone or working capital alone without subtracting inventories.

It is not especially surprising that the results across classes are so strong for the liquidity variables from the balance sheet. Cash flow is closely correlated with profits, and to the extent that there are problems with the $Q$ model or other investment demand specifications, one would expect cash flow to enter an investment equation positively, even for mature, high-dividend firms that are unlikely to face important cost disadvantages of external funds. On the other hand, stock measures of 
liquidity are less likely to indicate much about profitability of new investment. The evidence supports the hypothesis that these variables have no important effect for firms like the ones in our class 3 sample. For firms in classes 1 and 2, however, the results using balance sheet variables present strong evidence of the imperfect substitutability of internal and external finance at the margin.

We have examined the robustness of these results to alternative specifications. Because we have only current cash flow in the reported regressions, the estimated liquidity effects may be proxies for longer lags of cash flow, or they could capture accelerator effects of sales. To test this possibility, we included current and three lagged values of cash flow and sales in the model. The results are reported in the last half of table 10. The effects of these additional variables were statistically significant, but the pattern of estimated coefficients for the cash-andequivalents and working-capital-less-inventories variables are virtually identical to the patterns found in the models without sales or lags of cash flow.

INTERNAL FINANCE AND INVESTMENT IN HIGH-PAYOUT FIRMS

In some specifications of the investment models presented here, the estimated coefficient on cash flow is both statistically significant and economically important for the high-payout firms in class 3 . This finding was quite robust. We tried further splits of those firms based on the level of payout rates over the sample. We also divided those firms into groups based on dividend growth, rather than levels, to test the hypothesis that investment of firms that increase their dividends would be less sensitive to cash flow than firms that paid stable or falling dividends. The estimated cash flow coefficients for these subgroups were roughly the same as the estimated coefficients from the full class 3 sample.

Because class 3 firms pay substantial dividends, such findings may seem inconsistent with our emphasis on the imperfect substitutability of internal and external finance. That is, if external funds are more costly than internal finance, why would these firms not cut dividends rather than investment when cash flow falls? One explanation is that agency costs of internal finance (that is, potential "managerial waste" on less productive investments) account for this link between cash flow and 
investment in mature firms. ${ }^{48}$ While these agency problems may be important, they do not seem to explain the entire cash flow effect for class 3 firms. The class 3 cash flow effect is small when sales variables are included, suggesting that the apparent correlation between cash flow and investment in mature firms may be due to the omission of output terms important in reconciling the difference between marginal and average $Q$. Nor is there any measured effect of beginning-of-period stocks of liquidity on investment in these firms.

Furthermore, evidence of "sticky" dividends suggests that, in the presence of even small cost differentials between internal and external finance, investment may be sensitive to internal finance for mature firms with substantial payout. ${ }^{49}$ If these firms are reluctant to cut dividends when cash flow falls, maybe for signaling reasons, they may reduce investment somewhat rather than seek more costly external finance. This kind of behavior would, of course, magnify the importance of financial constraints for macroeconomic fluctuations in investment, a possibility that should be considered in more depth in future research.

\section{Conclusions and Applications}

Our results show that financial factors affect investment. Our approach emphasizes that the link between financing constraints and investment varies by type of firm. Recent literature on asymmetric information and capital market imperfections demonstrates that a firm's opportunity cost of internal funds can be substantially lower than its cost of external finance. Under these circumstances, the investment of firms that exhaust nearly all of their low-cost internal funds should be more sensitive to fluctuations in their cash flow than that of firms that pay high dividends. Also, liquidity should have a greater effect on investment for low-dividend firms than for high-dividend firms.

48. For a discussion of the agency costs associated with "free cash flows" in the petroleum industry, see Michael C. Jensen, "Agency Costs of Free Cash Flow, Corporate Finance, and Takeovers," American Economic Review, vol. 76 (May 1986, Papers and Proceedings, 1985), pp. 323-29.

49. See, for example, the review of studies presented in James M. Poterba, "Tax Policy and Corporate Saving,"'BPEA, 2:1987, pp. 455-503. 
To test these hypotheses, we estimated investment functions across groups of firms classified by their dividend behavior. Financial effects were generally important for investment in all firms. But the results consistently indicated a substantially greater sensitivity of investment to cash flow and liquidity in firms that retain nearly all of their income. This statistically and economically significant difference was robust to a wide variety of model specifications and estimation techniques. It was largest for sample periods in which the low-dividend firms were the youngest and had yet to be recognized by major financial data services. These empirically important differences across firms are consistent with financial constraints arising from capital market imperfections. The results also cast doubt on the longstanding interpretation of empirical financial effects on investment as proxies for misspecified "real" influences.

If capital market imperfections lead to binding financial constraints on investment, several important implications arise for the study of macroeconomic investment fluctuations and the impact of public policy on capital spending. We consider these points briefly, as well as some suggested directions for future research, in the remainder of the paper.

\section{INTERNAL FINANCE, INVESTMENT, AND ECONOMIC FLUCTUATIONS}

Financial constraints in capital markets can magnify the macroeconomic effect of shocks to cash flow or liquidity that reduce some firms' access to low-cost finance and worsen their balance sheet positions. To examine this issue more closely, we consider the extent to which internal finance effects on investment can account for the variability of aggregate investment. Since 1970, the standard deviation of the ratio of nonresidential gross investment to the replacement value of the stock of plant and equipment has been 0.87 percent (with a mean value of 12.46 percent). How much of this variance can be explained by our estimated effect of changes in cash flow in investment?

From the investment model estimated from the full sample with $Q$, current cash flow, and lags of sales, the cash flow coefficients for the dividend classes 1 through 3 are $0.309,0.167$, and 0.085 , respectively. We make the conservative assumptions that the effect of cash flow for the mature, high-payout firms in class 3 is not related to finance 
constraints, and that the portion of the class 1 and 2 coefficients equal to the class 3 coefficient should be attributed to effects other than finance constraints. Then the net cash flow effects for classes 1 and 2 are 0.224 and 0.082 , respectively. The predicted changes in the investment-capital ratio resulting from a one standard deviation change in the cash flow to capital ratios are 4.48 and 0.74 percentage points for classes 1 and 2, respectively.

The aggregate investment-capital ratio can be expressed as a weighted average of the ratio for each class, with weights equal to the proportion of the aggregate capital stock in each class. To predict the effect of cash flow changes for firms like those in classes 1 and 2 for aggregate investment fluctuations, therefore, one needs to estimate the proportion of the aggregate capital stock in similar firms. We begin very conservatively by assuming that the aggregate proportions are the same as our Value Line sample proportions. Then, one standard deviation changes in the class 1 and 2 cash-flow-to-capital ratios explain about 13 percent of the standard deviation in the aggregate investment-capital ratio.

This result, however, almost certainly understates the true effect because large, mature firms constitute a greater proportion of our Value Line sample than they do of the aggregate economy. Indeed, data for our sample period from the Quarterly Financial Reports of the U.S. Department of Commerce indicate that approximately 20 percent of aggregate assets are held by firms with total assets less than $\$ 100$ million. The median capital stock figure for our Value Line firms in class 1, certainly less than their total assets, was $\$ 95$ million in 1984. Class 2 firms had a median capital stock of $\$ 193$ million. These statistics imply that the aggregate importance of firms as small as or smaller than our class 1 and class 2 firms is much greater than our sample proportions would indicate, and the 13 percent figure derived above may well be a loose lower bound. The aggregate retention data also suggest that lowdividend firms are much more numerous and account for a much greater fraction of investment and capital in the economy as a whole than in our Value Line sample. Firms with assets less than $\$ 100$ million retained about 77 percent of their income. Therefore, the part of a representative aggregate shock to investment that could be explained by the kind of financial effects estimated here could be substantial, and financing constraints could account for a large proportion of the aggregate variability of investment. While only suggestive, such calculations provide 
further impetus to research that links aggregate economic fluctuations to problems in financial markets.

\section{FINANCE CONSTRAINTS, INVESTMENT, AND TAX POLICY}

Most studies of the effects of tax policy on investment assume that firms respond to prices set in centralized securities markets, such as market interest rates on Tobin's $q$, and that the availability of finance does not limit investment. The implications for tax policy are clear: what matters for investment is the marginal tax rate on returns from a new project, not the firm's average tax burden on returns from its investments in place. As we have emphasized, however, for firms that face imperfect markets for external finance, it is not sufficient to focus solely on the cost of funds determined in centralized securities markets. For these firms, the amount of earnings devoted to taxes, and therefore the average tax rate on returns from existing projects, matters for investment, possibly along with incentive effects of marginal tax rates. Thus, the cash flow effects of changes in the investment tax credit or depreciation allowances may be more important for many firms than the associated cost of capital effects of such policies. ${ }^{50}$

That average tax rates matter for some firms does not, however, necessarily imply a policy opportunity. To the extent that policymakers can distinguish project types no better than private financiers, the lemons problem remains. An additional concern relates to agency issues. Policies that increase internal finance might encourage managers concerned, for example, with corporate size as well as the value of shareholders' claims to overinvest. ${ }^{51}$ Nevertheless, understanding the impact of public poli-

50. These issues are considered in greater detail in Steven Fazzari, R. Glenn Hubbard, and Bruce Petersen, "Investment, Financing Decisions, and Tax Policy," American Economic Review, vol. 78 (May 1988, Papers and Proceedings, 1987), pp. 200-05.

51. At first glance, our finding that internal finance influences investment spending in addition to $q$, especially in firms with low payout, could be consistent with a managerial waste hypothesis: available internal finance is invested in projects at levels not justified by market signals alone. Our results show, however, that it is rapidly growing firms with high $q$ values, not large, mature or declining firms, that have low average payout and the greatest sensitivity of investment to the supply of internal funds. Therefore, tax changes that increase internal cash flow and liquidity could lead to higher levels of productive investment in some firms. 
cies on investment through their effect on internal finance can be important. As an example, asymmetric information problems reduce the likelihood that households can "pierce the corporate veil." Redistributions of funds away from firms, either to shareholders or to taxpayers, may change both the level of investment and its allocation to the extent that firms face information-related finance constraints.

\section{FURTHER EXTENSIONS AND LINKS TO OTHER CURRENT}

\section{RESEARCH}

The link between the financial influences on investment and information imperfections in capital markets suggests that research on "information capital" accumulation through financial intermediation is important for understanding the investment process. One channel through which information capital can be accumulated is financial institutions that specialize in long-term borrower relationships and in the evaluation of balance sheet positions. These institutions can figure prominently in the finance of smaller firms lacking cost-effective access to commercial paper, bond, and equity markets. Also, venture capitalists can be viewed as specialists in the accumulation of information on balance sheet positions and investment prospects in growing enterprises. The existence of a lemons premium in equity issues does not, however, imply that large arbitrage profits exist, where any cash-rich firm or individual could buy a constrained firm. Rather, "profits" arise from the costly activity of investigating and overcoming information asymmetries.

The existence of finance constraints has implications for research in industrial organization. Kenneth Judd and Petersen argue, for example, that large differentials in the cost of internal and external finance can rationalize predatory and limit-pricing strategies. In addition, interesting evidence provided by David Ravenscraft and F. M. Scherer supports the view that many mergers appear to match different corporations that face different costs of capital on the margin. ${ }^{52}$ Such combinations would

52. Kenneth L. Judd and Bruce C. Petersen, "Dynamic Limit Pricing and Internal Finance," Journal of Economic Theory, vol. 39 (April 1986), pp. 268-99; David J. Ravenscraft and F. M. Scherer, Mergers, Sell-Offs, and Economic Efficiency (Brookings, 1987). 
permit reallocations of capital that bypass capital markets. This possibility suggests other research questions, some which have been addressed by Ravenscraft and Scherer. Do mergers of companies in related activities perform better than purely conglomerate mergers, and if so, are the reasons information-related? How do young firms that are independent perform relative to those acquired by cash-rich mature companies? Similarly, how do start-up ventures of cash-rich companies perform relative to independent start-up ventures?

Our empirical results on firm investment suggest that models should address links between net worth and credit allocation and the possibility of precautionary retentions by many firms. Theoretical research is proceeding along these lines..$^{53}$

Future research should consider the role of internal finance in investment decisions in other countries, examining differences in tax policies, the structure of capital markets, and organization of firms. A particularly interesting topic would be the analysis of differences in the sensitivity of investment to internal finance according to the extent to which lenders participate in corporate decisionmaking. Research in these areas is just beginning, but the importance of internal finance for investment has been confirmed using firm data for Japan and for the United Kingdom. ${ }^{54}$

These results are also relevant to debates over the source of aggregate fluctuations. The importance of firm heterogeneity in capital markets suggests that representative agent, real business-cycle models, in which financial factors are irrelevant and productivity shocks drive macroeconomic movements, are not likely to be adequate descriptions of cyclical fluctuations. On a formal level, models should consider channels through which exogenous shocks are magnified by information imperfections in capital markets.

53. Roger E. A. Farmer, “A New Theory of Aggregate Supply," American Economic Review, vol.74(December 1984), pp.920-30; Bernanke and Gertler, "Financial Fragility"; Calomiris and Hubbard, "Firm Heterogeneity"; Bruce Greenwald and Joseph E. Stiglitz, "Information, Finance Constraints, and Business Fluctuations" (Princeton University, 1986).

54. Takeo Hoshi, Anil K. Kashyap, and David Scharfstein, "Corporate Structure and Investment: Evidence from Japanese Panel Data" (MIT, May 1988); Richard Blundell, Stephen Bond, Michael Devereux, and Fabio Schiantarelli, "Does $Q$ Matter for Investment? Some Evidence from a Panel of U.K. Companies," Working Paper 8712 (London: Institute for Fiscal Studies, December 1987). 


\section{APPENDIX A}

\section{Dividends, Investment, and Q under Alternative Financing Regimes}

WE BEGIN with a simple model of equity finance, dividends, and investment. ${ }^{55}$ In tax-based models, there are differences in the costs of internal and external finance because of the differential taxation of capital gains and dividends at the personal level. In any period $t$, an existing shareholder's after-tax return $R_{t}$ is the sum of a dividend return (taxed at rate $\theta$ ) and a capital gain (taxed at an accrual-equivalent rate $c$ ), so that

$$
R_{t}=\frac{(1-\theta) D_{t}+(1-c)\left({ }_{t} V_{t+1}-V_{t}\right)}{V_{t}},
$$

where $D_{t}$ represents the dividend payment by the firm, $V_{t}$ is the value of the firm's equity, and ${ }_{t} V_{t+1}$ is the value in period $t+1$ of the shares outstanding in period $t$. In period $t+1$, the total value of the firm is

$$
V_{t+1}={ }_{t} V_{t+1}+V_{t}^{N},
$$

where $V_{t}^{N}$ represents new share issues.

In equilibrium, owners of equity earn their required return $\rho$, so that

$$
\rho V_{t}=(1-\theta) D_{t}-(1-c) V_{t}^{N}+(1-c) V_{t+1}-(1-c) V_{t},
$$

and the value of the firm is given by

$$
V_{t}=\sum_{i=0}^{\infty}\left(1+\frac{\rho}{1-c}\right)^{-(i-1)}\left[\left(\frac{1-\theta}{1-c}\right) D_{t+i}-V_{t+i}^{N}\right] .
$$

That is, the total value of the firm is the present value of the posttax dividend stream adjusted for the present value of new share issues that would have to be bought by current equity holders to maintain their proportional claim on the firm.

55. See the discussions in Alan J. Auerbach, "Taxes, Firm Financial Policy and the Cost of Capital: An Empirical Analysis,' Journal of Public Economics, vol. 23 (FebruaryMarch 1984), pp. 27-57; and Poterba and Summers, "The Economic Effects of Dividend Taxation." 
To take into account the lemons premium associated with new equity issues, as we discussed in the text, we reduce $V$ in equation A. 4 by an amount $\Omega$ per dollar of new equity issued. That is,

$$
V_{t}=\sum_{i=0}^{\infty}\left(1+\frac{\rho}{1-c}\right)^{-(i-1)}\left[\left(\frac{1-\theta}{1-c}\right) D_{t+\mathrm{i}}-\left(1+\Omega_{t+\mathrm{i}}\right) V_{t+i}^{N}\right]
$$

The firm maximizes its market value subject to a set of four constraints.

-Capital accumulation: $K_{t}=(1-\delta) K_{t-1}+I_{t}$, where $K_{t}$ is the capital stock at the end of period $t, I$ represents investment, and $\delta$ represents a constant rate of depreciation.

-Sources equal uses of funds: $(1-\tau) \pi\left(K_{t}\right)+V_{t}^{N}=D_{t}+I_{t}$, where $\pi(K)$ represents pretax profits and $\tau$ is the corporate income tax rate.

-Dividends: $D_{t} \geq 0$.

-New share issues: $V_{t}^{N} \geq V^{N}$; that is, new share issues are assumed to be bounded from below by some minimum (negative) level, $V^{N}$.

In summary, the firm chooses $I, K, V^{N}$, and $D$ so as to maximize $V$ subject to the constraints described above. That is,

$$
\begin{aligned}
\max \sum_{t=0}^{\infty} & \left(1+\frac{\rho}{1-c}\right)^{-(t-1)}\left\{\left[\left(\frac{1-\theta}{1-c}\right) D_{t}-\left(1+\Omega_{t}\right) V_{t}^{N}\right]\right. \\
& \left.-\lambda_{t}\left[K_{t}-(1-\delta) K_{t-1}-I_{t}\right]\right\} \\
& -\alpha_{t}\left[(1-\tau) \pi\left(K_{t}\right)+V_{t}^{N}-D_{t}-I_{t}\right] \\
& -\beta_{t}\left(V_{t}^{N}-V^{N}\right)-\gamma_{t} D_{t},
\end{aligned}
$$

where $\lambda, \alpha, \beta, \gamma$ are the Lagrange multipliers associated with the constraints.

The solution for the case where internal finance exceeds investment is familiar. In that case, if the dividend tax rate exceeds the capital gains tax rate $(\theta>c)$, it is never optimal to issue new shares and pay dividends at the same time. Abstracting from corporate tax considerations, the equilibrium value of an additional unit of capital-marginal $q$-is equal to $(1-\theta) /(1-c)$. This is the $q$ value at which shareholders are indifferent between a dollar of retentions reinvested in the firm and taxed at rate $c$, and a dollar of dividends taxed at rate $\theta$. 
New shares are issued only when internal finance is exhausted and the marginal $q$ on additional projects exceeds $1+\Omega$. The range of $q$ values over which firms neither pay dividends nor issue new shares can be derived as follows. When firms are not paying dividends and internal finance is exhausted, we know that $\beta_{t}=0$ and

$$
\alpha_{t}=-1-\Omega_{t} \text {. }
$$

Given the lemons discount, firms will choose to issue shares only when

$$
\lambda_{t} \geq 1+\Omega_{t},
$$

so that the supply-of-funds schedule facing the firm has a discontinuity at the point where retentions are exhausted.

APPENDIX B

\section{Data Base and Variables}

OUR DATA SAMPLE was the annual Value Line data base, updated in April 1986. The data cover manufacturing firms (two-digit SIC codes between 20 and 39, inclusive). Firms were included in the sample only if they had observations for each year from 1969 through 1984. The 1969 data were used only for constructing lags. We used earlier data, when available, to construct longer lags for some of the tests described in tables 4 and 5 . We chose 1969 as the starting point because inventory data necessary to construct the $Q$ variable were available only from 1969 onward. We excluded 1985 because the number of firms with observations in 1985 dropped substantially.

Firms that had mergers valued at more than 10 percent of their capital stock were excluded from the sample because large mergers could lead to inconsistencies when constructing the ratios used in the regressions. Merger data were taken from the COMPUSTAT data base. The merger deletions occurred almost exclusively among mature firms, and they did not materially affect the reported results. Several observations were deleted because of missing data for individual variables necessary for the regressions. Three firms were deleted because of major inconsistencies between their capital ștock and investment data. Two firms were moved from the first to the second class, and one firm from the first to 
the third class, because of substantial and frequent share repurchases that functioned like dividends. Share repurchases in the remainder of the first class firms were zero or negligible. Further details concerning the data are available from the authors.

Market value of equity $(V)$. The value of common stock at the beginning of the year is the average price over the last fiscal quarter of the previous year times the number of shares outstanding at the end of the previous fiscal year. For the preferred stock, we compute the market value by dividing preferred dividends by the preferred stock yield from Standard and Poor's.

Value of debt $(B)$. The results in the text are based on the book value of short-term and long-term debt. We also considered the effect of estimating the market value of long-term debt as follows. Value Line data provide the interest paid on long-term debt. The ratio of this variable to the book value of long-term debt gives an estimate of the debt's average coupon raie $\left(r_{c}\right)$. To avoid the effect of outliers, this ratio was limited at a 10 percent premium over the Baa corporate bond rate. Following Michael Salinger and Lawrence Summers, we assumed all long-term debt carries a Baa rating. ${ }^{56}$ Then the market value of longterm debt can be estimated by $\left[\left(1+r_{B a a}\right) /\left(1+r_{c}\right)\right]^{M}$ times the book value, where $r_{B a a}$ is the market rate on Baa debt and $M$ is the average time to maturity of the existing debt. We made this adjustment for $M$ values of $5,10,15$, and 20 years, reflecting the fact that the maturity of outstanding debt across our retention classes is likely different. None of these calculations, however, changed the pattern of the reported $Q$ values or regression results for any of the $M$ values, relative to the results with book values presented in the text.

We also considered the possibility that the debt of firms in the first class was more risky than Baa debt, in which case the adjustments described above would overstate the value of debt in class 1 and could bias the $q$ measurements upward. We assumed that any difference between $r_{c}$ and $r_{B a a}$ was a risk premium, and computed $q$ with the debt discounted accordingly. Again, this modification produced virtually no difference in the statistics relative to the book-value calculations.

56. Michael A. Salinger and Lawrence H. Summers, "Tax Reform and Corporate Investment: A Microeconomic Simulation Study," in Martin Feldstein, ed., Behavioral Simulation Methods in Tax Policy Analysis (University of Chicago Press, 1983), pp. 247-81. 
Replacement value of the capital stock $(K) . K_{t}$ represents the capital stock at the beginning of period $t$. The replacement value of property, plant, and equipment is estimated from book values using a method similar to that of Salinger and Summers. We set the initial value of $K$ to the value of net plant (adjusted to market value with aggregate data) for the first year the firm appears on the Value Line data base. The capital stock is then defined iteratively as

$$
K_{t}=\left[I_{t}+\left(P_{t} / P_{t-1}\right) K_{t-1}\right](1-1 / \text { LIFE }),
$$

where $P_{t}$ is the implicit price deflator for fixed nonresidential investment, $I_{t}$ is the firm's capital spending, and LIFE is the average service life implicit in the firm's book depreciation costs. The final term is based on the assumption that economic depreciation is single-declining balance. Our results did not change substantially when we assumed doubledeclining balance economic depreciation. For mature firms, the starting point for this procedure generally stretched back to the late 1950s. For newer firms, the initial book value of their capital stock probably is a good estimate of its replacement cost. Thus, the capital stock estimates should exhibit little inflationary bias for our sample that begins in 1969.

Tax parameters for $Q$. As in Salinger and Summers, we assume that tax policy parameters remain constant, and that the sum of the required rates of return on investment and expected inflation is equivalent to the nominal Baa bond rate plus 0.06 . That is, we let

$$
X_{t}=\tau z\left[\frac{1-\theta}{1-c}\right] K_{t},
$$

where $\tau$ represents the corporate income tax rate, $\pi$ represents inflation, and $K_{t}$ is the nominal replacement value of the capital stock and

$$
z=\left[\frac{\delta}{\delta+\frac{\rho+\pi}{1-c}}\right] .
$$

Tax depreciation is assumed to be double-declining balance at rate $\delta=2 /$ LIFE. The average effective tax rate on dividends $(\theta)$ and capital gains $(c)$ are taken from James Poterba. ${ }^{57}$ The corporate tax rate $\tau$ was set at the statutory maximum marginal rate. 
Market value of inventories $(N)$. Because inventories are included in the market valuation of the firm, but not in the replacement cost of the fixed capital stock, we subtract $N$ from the market value of the firm. There was no substantial difference in the results when $N$ was instead added to the replacement cost of the firm's capital stock. Inventories for each firm are converted from book value to market value using the procedure outlined in Salinger and Summers and Value Line data concerning whether the firm uses LIFO and FIFO methods of inventory accounting.

Investment tax credit $(k)$. Information on legislated values of the investment tax credit was taken from the Washington University Macro Model. Information on the mix between equipment and structure was taken from aggregate data.

Cash flow $(C F)$. Cash flow, as defined by Value Line, equals income after interest and taxes, plus all noncash deductions from income (principally depreciation allowances and amortization). Dividends were not subtracted from cash flow.

$Q$ definitions. Using these components, we have constructed three $Q$ measures:

Tobin's $q=(V+B-N) / K$; Tax-adjusted $Q=(1-\tau)^{-1}\left[\frac{V+B-X-N}{K}-(1-k-\tau z)\right] ;$ and
(no dividends paid)

Tax-adjusted $Q=(1-\tau)^{-1}\left[\left(\frac{1-c}{1-\theta}\right)\left(\frac{V-X}{K}\right)+\frac{B-N}{K}-(1-k-\tau z)\right]$
(dividends paid)

Cost of capital ( $r)$. The cost of capital is given by

$$
r=\left(\frac{p_{k}}{p}\right)\left(\frac{1-k-\tau z}{1-\rho}\right)\left[(1-L)\left(\frac{1-\theta}{1-c}\right) i+(1-\tau) i L-\pi^{e}+\delta\right],
$$

where

$p_{k}=$ implicit price deflator for capital goods

$p=$ implicit price deflator for nonfarm business output

$\tau=$ corporate income tax rate

$k=$ investment tax credit rate 
$z=$ present value of one dollar of depreciation allowances

$\theta=$ marginal effective personal tax rate on dividend income

$c=$ marginal effective personal tax rate on capital gains

$L=$ average proportion of marginal investment financed with debt

$i=$ average nominal Baa corporate bond rate

$\pi^{e}=$ expected inflation rate

$\delta=$ economic depreciation rate. 


\title{
Comments and Discussion
}

\begin{abstract}
Alan S. Blinder: A few years ago, in revising my graduate course reading list, I looked for some modern literature on liquidity constraints and investment analogous to the burgeoning literature on liquidity effects on consumption. There was none. Now there is, thanks to the sterling efforts of Steven Fazzari, Glenn Hubbard, and Bruce Petersen. So, lest what I have to say sound critical, I want to state clearly that the potential effects of cash flow on investment was a research question crying out to be asked theoretically and then answered empirically. The authors, in this paper and its predecessor, attempt to do both. For that, they deserve credit, maybe even cash.
\end{abstract}

Empirically, there are striking parallels between consumption and investment. As we all know, consumption seems to respond strongly to current income and weakly, if at all, to interest rates. The stylized facts from business investment equations are much the same: a strong response to sales or output and a weak response to the cost of capital. These four econometric findings pose challenges to economic theory.

I start with income sensitivities, since they are most germane to the authors' work. Milton Friedman and Franco Modigliani suggested decades ago that if consumption decisions arise from intertemporal optimization, then current income should have little effect on current consumption. Yet the observed effect is strong. Modern consumption theorists append rational expectations to the Friedman-Modigliani framework and offer two explanations: the theory is right, but current income is an excellent predictor of future income; the theory is wrong, perhaps because of liquidity constraints.

In the case of investment, the empirical puzzle runs deeper and the explanations run shallower. Basic neoclassical theory denies any role to current output; only relative factor prices should drive investment. As economists realized in the $1950 \mathrm{~s}$, but forced themselves to forget in the 
1960s and 1970s, liquidity constraints offer one possible explanation: short-run fluctuations of GNP have large effects on cash flow, which is a cheaper source of finance than external funds. The authors resurrect this 1950 s view, but rationalize it not by transactions costs-though they do mention them-but rather by 1980s-style theorizing based on informational asymmetries. I like this line of theorizing, though I think there is a tendency to carry it too far. For example, were most capital markets closed to Steven Jobs in 1975 because of the lemons problem, or was it because the risk was so great? Similarly, did General Motors finance its recent multibillion dollar investment campaign so easily because information was symmetric or because its pockets were so deep? We should insist on evidence that informational problems are more important in practice than simpler explanations like transactions costs.

Now, what of interest rates? It is by now widely agreed that saving is not sensitive to rates of return. The standard explanation is that income effects cancel substitution effects. This explanation, of course, will not do for investment because profit maximization precludes income effects. Yet the stylized fact is much the same: you have to torture the data pretty ruthlessly before they confess to an interest elasticity of investment. Why? One possibility is that business managers do not maximize profits. I return to that heresy at the end of my comments.

The authors' explanation is, once again, the financing hierarchy. If the marginal cost of funds looks like a staircase with narrow treads and big risers (see the authors' figure 1), then many firms will find their optimum on the risers rather than on the treads. For such firms, a vertical upward or downward shift of the whole staircase (a change in the cost of capital) will have no effect on investment, but a widening of the relevant tread (a change in credit availability) will change investment. Obviously, the story is more important empirically when the risers are tall than when they are short (again, see figure 1). In the authors' theory, the heights depend on the severity of informational asymmetries. In a more naive theory, they depend on transactions costs.

Although the model favored by the authors is consistent with the stylized facts, it is not the only possible explanation. Matthew Shapiro offered a different explanation for these same facts two years ago at a meeting of this panel. ${ }^{1}$ His was that frequent, large shocks to productivity

1. Matthew D. Shapiro, "Investment, Output, and the Cost of Capital," BPEA, 1:1986, pp. 111-52. 
simultaneously raise output, investment, and interest rates. As I recall, Shapiro was all but hooted out of the room-Washington being too far from the Great Lakes to make his story believable, especially in a crowd more favorably disposed toward liquidity constraints. But we should still insist on empirical evidence.

Fazzari, Hubbard, and Petersen provide some. Their basic empirical idea is a good one. To see whether investment spending is sensitive to cash flow, they try to identify, on a priori grounds, the firms most likely to encounter liquidity constraints. They suggest dividend behavior as the telltale sign: firms with very low dividend payout rates are arguably more likely to be liquidity constrained than firms with more normal payout rates. I understand the argument. But it makes me a bit uneasy because it is so puzzling that firms pay any dividends at all. It takes exceedingly clever theoretical arguments to rationalize this apparently irrational behavior.

I also have an econometric source of unease. Dividend payout rates are endogenous and, in particular, are probably sensitive to unobserved investment prospects. The authors' basic regression is:

$$
I / K=a Q+b(\text { Cash flow } / K)+u .
$$

Firms that draw large positive $u$ 's will probably choose low payouts and hence wind up in classes 1 and 2 while firms with large negative $u$ 's will wind up in class 3 . That starts to sound like truncating on the error term. I'm only a good enough econometrician to worry about that problem, not to figure out whether including fixed effects, as the authors do, takes care of it.

It seems to me that there are other ways to divide the sample-old versus young firms or small versus large ones-that are freer of this problem and relate better to the information-based theories to which the authors appeal. Of course, these attributes are correlated with dividend policy; so perhaps the results would look much the same. However, dividend policy, age, and size are not perfectly correlated; so alternatives are perhaps worth exploring.

Dividing the sample in different ways has one further virtue. As I have noted, the financing staircase can arise from several sources. The lemons explanation that the authors favor suggests that young versus old might be the key distinction. Theories based on deep versus shallow pockets or on fixed flotation costs suggest that small versus large may be the key distinction. 
The results the authors obtain are stunningly strong and important. In regressions like equation 1, estimates of $b$ are large and significant, even though very small firms and start-ups are not in the Value Line sample. In fact, the results are too strong and too robust. Cash flow seems to affect investment strongly even in class 3 firms, which have an average 1984 capital stock of $\$ 2$ billion and an average payout rate of about 40 percent. Look, for example, at table 4, which uses the authors' favorite theory, the $Q$ theory. The equation for the full period says that, at the margin, a one dollar increase in cash flow raises investment spending by 23 cents. That's a lot. Can we really believe that lending to one of these billion-dollar firms is like buying a used car from a stranger? I know I'd rather buy a used bond from Chrysler than a used Chrysler from Bond.

Here is a second problem. It seems to me that the staircase theory argues not only that cash flow should be more important in classes 1 and 2 , which the authors always find, but also that cost of capital effects should be less important. In table 4, this is not true: $Q$ matters most in class 2 . And in table 8, the Jorgenson term matters most in class 1 and least in class 3.

Finally, let me say something about the most boring issue in macroeconomics: stock versus flows. It seems to me that liquidity constraints should pertain to stocks, not to flows. I can understand why a firm with limited access to external capital might find its holdings of physical capital constrained by internal funds. But I have a hard time understanding how a low current cash flow could constrain the net acquisition of capital by a firm with a large accumulated stock of cash. Yet table 10 shows that cash flows matter more than cash stocks and that adding stocks does not reduce the coefficients of cash flow very much.

I can think of two possible explanations. The first is that the equation is misspecified: it should relate the desired capital stock to cash stocks and append an adjustment mechanism through which current cash flows influence the adjustment of actual to desired capital. The second is that the constraining variable for current investment is actually opening cash stock plus current cash flow, and cash flows are bigger and more variable than opening stocks, so they dominate econometrically. I have no idea if either of these explanations holds water.

One last remark. At the end of their paper, the authors dismiss the "managerial waste" hypothesis: that managers invest internal funds even if the investments are not profitable. I would not dismiss it so 
lightly. Perhaps managers of large firms treat internal funds as costless and hate to go to the market. How else are we to explain the influence of cash flow on the investment of billion-dollar firms? Maybe managers are like mountain climbers: they invest the money "because it is there." That, I suppose, is what Carl Icahn and Boone Pickens believe. They are certainly rich. Maybe they are also smart.

James M. Poterba: Empirical comparisons between the simple accelerator, neoclassical accelerator, $Q$ theory, and cash flow models of aggregate U.S. investment have usually favored the simple accelerator specification. Nevertheless, textbook and classroom expositions of business investment tend to rely on either the neoclassical accelerator or $Q$ model, since they can be grounded more formally in economic theory. This provocative and important paper seeks to change the way we think about the investment function in two ways. First, it marshals a convincing theoretical case based on credit market imperfections for the proposition that cash flow may significantly affect investment outlays. Economic theory suggests many reasons why firms may be cash constrained when making investment outlays. Second, after removing the central obstacle to the respectability of the cash flow model, the paper shows that cash flow variables substantially improve the explanatory power of investment equations estimated using individual firm data. The paper breaks new ground in explicitly modeling firm heterogeneity with respect to investment rules and in demonstrating that cash flow plays a more important role in investment decisions of small firms that retain most of their earnings.

There is more to compliment than to quarrel with in this paper. My comments will reflect this, focusing on three questions that arise in evaluating the paper. First, is the link between cash flow and investment operative primarily for low-dividend firms, or is it likely to be significant for mature firms as well? Second, do the paper's empirical results significantly sharpen our knowledge of how cash flow affects investment? Third, how well do the present results, for a sample of manufacturing firms, extrapolate to the economy at large? I shall consider these questions in turn.

The authors are undoubtedly correct in arguing that some small, lowdividend firms face cash flow constraints when undertaking new investments. Even for mature dividend-paying firms, however, I suspect (and 
the paper's empirical results confirm) the potential importance of cash flow. Several strands of prior evidence buttress the view that cash flow may be more influential for large firms than the authors claim. First, mature dividend-paying firms cannot costlessly reduce their dividends. Share prices fall when firms cut their dividends: the most recent study shows a 2 percent decline in prices when a firm reduces its dividend, and an 8 percent decline if a firm completely omits a dividend. ${ }^{1}$ For a firm with a dividend yield of 4 percent a year, omitting the dividend for a oneyear period will reduce share values by twice as much as the increment to investment funds. This suggests significant costs to dividend cuts, but it may also place an upper bound on the potential cost of external funds for mature firms. Anecdotal evidence also suggests the difficulty of dividend reduction. In 1968 when General Utilities tried to omit its dividends to finance investment projects, shareholders protested violently and eventually the management agreed to continue the dividend and resort to external finance. ${ }^{2}$

Second, previous empirical studies of rates of return are consistent with the view that internal finance is perceived as less costly than external funds. ${ }^{3}$ Ex post profit rates are higher for firms that use external finance, particularly external equity, than for firms that rely on internal finance. These results are difficult to interpret because they may demonstrate only that firms with good earnings prospects can convince investors of their favorable future returns, but they are nevertheless consistent with this paper's results. They are not restricted to small firms, althought it might be interesting to reexamine the earlier tests using the type of firm stratification rule developed in the present paper.

Third, the asymmetric information problems that are invoked to explain credit market failures for small firms appear to affect both large and small firms. The voluminous literature on the valuation consequences of changes in capital structure, finding positive returns to transactions that add debt or replace equity with debt, and negative

1. Kenneth M. Eades, Patrick J. Hess, and E. Han Kim, "Market Rationality and Dividend Announcements," Journal of Financial Economics, vol. 14 (December 1985), pp. 581-604.

2. "A Case for Dropping Dividends," Fortune, June 15, 1968, p. 181.

3. References to this literature, and some constructive empirical evidence, may be found in Alan J. Auerbach, "Taxes, Firm Financial Policy and the Cost of Capital: An Empirical Analysis," Journal of Public Economics, vol. 23 (February-March 1984), pp. 27-57. 
returns for equity issues, shows that firms are affected across size categories. Of course, it may be that if significant capital structure changes were observed for smaller firms, the valuation effects would be even larger than those for mature firms. This evidence nevertheless suggests the potential importance of imperfect information even for large firms.

While the a priori case for believing this paper's central theme is strong, that does not simplify the task of determining how much investment results from shocks to corporate cash flow. That must be answered on the basis of the empirical results, where some caution is required. The authors report investment equations for three groups of firms stratified on the basis of dividend payout and show that the link between investment and cash flow is substantially stronger for low-payout than for high-payout firms, even after controlling for Tobin's $q$. The key question is whether shocks to cash flow are transmitted to investment outlays, or whether other uses of funds, such as repurchasing shares or buying back or issuing debt, serve as shock absorbers when earnings fluctuate.

Earlier studies of investment and cash flow were dismissed partly because shocks to cash flow signal two things: an increase in current liquidity and a potential improvement in future profitability. The present paper is much more careful about this problem than previous investment studies. By controlling for the beginning-of-year value of Tobin's $q$, the investment equations reduce the informational content of current cash flow. They do not eliminate it, however, and this clouds the results. There are many reasons for suspecting that measured $Q$ is not a sufficient statistic for future cash flows. These range from difficulties in measuring the replacement cost of the firm's assets, to concern over whether average $Q$ is a good proxy for marginal $Q$, to questions about the informational content of stock prices themselves. If for any of these reasons the measured $Q$ variable provides an error-ridden indicator of the firm's true prospects, then econometric results may find that current cash flow affects investment only because this variable, just like measured $Q$, is correlated with the "true" marginal $Q$ variable that firms consider in making investment decisions. The pattern of results across different classes of firms could be explained on this view because $Q$ is measured with more error for smaller firms, which tend to be lowerdividend firms. The authors recognize these potential difficulties, and 
allude to instrumental variable results where the current cash flow variable is treated as endogenous. These results are unfortunately not reported, even though they are easier to interpret than the ordinary least squares estimates. Similarly, the authors mention but do not report equations including Tobin's $q$ from the end of the current period as well as the end of the previous period. The coefficients on cash flow in these equations are somewhat cleaner than those from the models with only lagged $Q$, since they avoid biases that result when cash flow incorporates later information than the $Q$ variable.

One particular source of error that illustrates these problems concerns tax losses. Although the paper uses microeconomic data, the authors assume that all firms face identical tax parameters. In practice, some firms have tax loss carryforwards that prevent them from taking advantage of the investment tax credit and depreciation allowances that are available to the "representative firm." For tax loss firms, the assumption that they can claim full tax benefits induces a measurement error in $Q$. Moreover, since a firm's current cash flow is almost certainly correlated with its tax status, the measurement error is correlated with the cash flow variable. A standard errors-in-variables argument could therefore account for the cash flow coefficients. Instrumental variables estimates using the lagged value of $Q$, or equations that ignore the tax factors completely, may fail to remedy these problems. Further work, with more explicit modeling of the measurement error dynamics, would help, since definitive support for credit market effects must resolve these issues.

The final question I consider involves the authors' efforts to generalize their results. Within the sample, approximately 1 percent of total investment was undertaken by firms in class 1 , and another 2.3 percent by firms in class 2 . This understates the importance of cash flow factors as sources of investment fluctuation, however, since the authors correctly observe that cash flow is more variable for their class 1 and 2 firms than for the mature class 3 corporations. The paper's extrapolations are probably too sweeping, however. The paper notes that over 20 percent of assets in manufacturing are held by firms that are as small as, or smaller than, the firms in class 1 . The trouble with inferring that they all face tight borrowing constraints is that firms with traded equity (a precondition for being in the sample) may be a selected group that has both substantial investment needs and weak access to bank credit. It 
may therefore be difficult to extrapolate the results to the rest of the manufacturing sector.

It is even more difficult to generalize to nonmanufacturing firms, which held over 70 percent of corporate plant and equipment at the end of 1986. Some assets, such as cars, cash registers, and computers, can serve as collateral for bank loans. Firms that invest heavily in such standardized assets probably face much easier hurdles on external finance than do more specialized manufacturing firms that purchase unique assets. Firms outside manufacturing are also likely to experience more stable cash flow: a 1 percent change in GNP translates into more than a 2.2 percent change in manufacturing output. This suggests that the cash flow considerations that are highlighted here may be less central in other parts of the economy. Conclusions about the importance of cash flow factors in these sectors must therefore await evidence on the behavior of nonmanufacturing firms.

In testimony to the important and provocative nature of this paper, studies generalizing the present methodology to other samples of firms, in other industries and other countries, have already begun to appear. There is little doubt that future research on corporate investment and capital markets more generally will have to reckon with the authors' revivification of the cash flow model of capital spending.

\section{General Discussion}

Some participants discussed the reliability of the authors' empirical results. Elaborating on Alan Blinder's comments, Christopher Sims suggested that the authors should have grouped the firms according to some essentially exogenous characteristic such as size or age rather than by their dividend-income ratio. It is not sufficient to argue that all class 1 firms are small or young, because a considerable percentage of the small and young firms might be in classes 2 and 3. Even in that case a simultaneity bias will remain. James Tobin noted that the firm jointly determines investment, dividend payments, and other ways of allocating its cash flow. Therefore, he suggested that the authors model investment and dividends as depending on the same set of explanatory variables.

Sims went on to describe two other potential pitfalls of the authors' econometric method. First, cash flow may be a key source of information 
to the firm about future profitability. Hence investment should be correlated with cash flow even with perfect capital markets. The present results may simply indicate that the information content of cash flow is greater for class 1 firms, which are almost all small and young. Second, even in the absence of a correlation between investment opportunities and cash flow in the entire population of firms, it is possible that the authors' method of classification will group together firms that, by chance, have cash flow roughly equal to their investment needs.

William Brainard concurred with Sims's argument, observing that the typical class 1 firm is likely to have a low variance of its dividend payout ratio as well as a low average. Since dividends themselves tend to be infrequently changed, most of the variation in a firm's payout ratio is likely to reflect variations in the denominator, its earnings. High earnings variability presumably reduces the information content of current earnings for the profitability of investment. Hence the firms excluded from class 1 would be expected to have a lower correlation of cash flow and investment, even with perfect capital markets. Joseph Stiglitz suggested a more powerful method to test for the importance of the cash flow constraint. If the cash flow constraint is actually binding, then one should find a clustering of investment levels around the constraint. On the other hand, if investment is far away from the constraint, then it is likely that a significant coefficient on cash flow is spurious.

Robert Hall was generally skeptical about the progress of empirical work on investment. He noted that most investment equations, including his own earlier work with Jorgenson and the present equations of the authors, suffer from an identification problem. Because the right-handside variables are invariably endogenous, there is no way to determine what is driving what.

Discussion turned to Blinder's question of why cash flow rather than the stock of cash is the relevant variable for investment equations. It is difficult to argue that a firm with low cash flow is constrained if it holds substantial liquid assets. James Poterba noted that a firm that builds up large stocks of cash for future investments is considered a cash cow: a prime target for takeovers. A firm may therefore soak up excess cash flow by investing incrementally rather than acquiring stocks of cash. This would tend to make investment more highly correlated with cash flow than with stocks of cash. Stiglitz suggested that the liquidity of a firm includes its lines of credit as well as its stock of cash. This is an 
alternative explanation of why the stock of cash has little explanatory power in cross-sectional investment equations even if finance constraints are important. Stiglitz also noted that for a variety of reasons firms may want to maintain a certain ratio of capital to cash on their balance sheet. Thus the stock of cash may actually increase with investment, contrary to what would be expected in a liquidity-constrained world.

Stiglitz noted that imperfect information is a key reason for constraints on external financing, for both large and small firms. Therefore he was not surprised by the economically significant cash flow coefficients even for the larger class 3 firms. Ben Bernanke drew parallels between the authors' work and earlier work of Feldstein and Horioka, who found that for smaller countries investment often equals savings. Thus small countries, as well as small corporations, apparently face external finance constraints. 